\title{
O DELITO DE ESTUPRO NO CÓDIGO PENAL BRASILEIRO: QUESTÕES CONTROVERTIDAS EM FACE DOS PRINCÍPIOS CONSTITUCIONAIS E A PROPOSTA DESSE DELITO NO NOVO CÓDIGO PENAL
}

José Renato Martins

ISSUE DOI: 10.21207/1983.4225.309

\section{RESUMO}

Este trabalho foi realizado com o objetivo de apresentar e discutir a estrutura analítica do delito de estupro contido no Código Penal, particularmente após a alteração legislativa promovida pela Lei $\mathrm{n}^{\circ} 12.015 / 09$, partindo-se do registro de considerações preliminares sobre o delito em questão, analisando-se sua evolução histórica no direito brasileiro, seus elementos componentes e as questões controvertidas relacionadas ao mesmo, sob a ótica dos princípios constitucionais, bem como a proposta desse delito no Projeto do Novo Código Penal, concluindo-se, ao final, reflexiva e criticamente sobre esse tema de extrema importância para o direito penal. 
Palavras-chave: Delito de estupro. Questões controvertidas. Princípios constitucionais. Novo Código Penal.

\section{INTRODUÇÃO}

O tema proposto está relacionado diretamente com o Direito em sua constante evolução, particularmente com o direito penal, mas também com a própria sociedade.

A evolução do Direito não ocorre de maneira contemporânea às transformações cotidianas da sociedade, na medida em que busca, exatamente, a solução dos novos conflitos.

Assim, sem a pretensão de analisar as diversas concepções, conceitos e fundamentos, poder-se-ia entender o Direito como o instrumento utilizado pelos seres humanos para regular a vida em sociedade.

De fato, hodiernamente, predomina o entendimento entre aqueles que se dedicam ao estudo das ciências jurídicas de que ubi societas ibi jus, isto é, não há sociedade sem Direito, conclusão a que se pode chegar a partir da verificação de que a função exercida pelo Direito na sociedade é ordenadora, ou seja, "de coordenação dos interesses que se manifestam na vida social, de modo a organizar a cooperação entre pessoas e compor os conflitos que se verificarem entre seus membros". ${ }^{74}$

Conforme lecionam os professores Antonio Carlos de Araújo Cintra, Ada Pellegrini Grinover e Cândido Rangel Dinamarco, o motivo para tal conclusão está

na função que o Direito exerce na sociedade: a função ordenadora, isto é, de coordenação dos interesses que se manifestam na vida social, de modo a organizar a cooperação entre pessoas e compor os conflitos que se verificarem entre seus membros. ${ }^{75}$

${ }^{74}$ CINTRA, Antonio Carlos de Araújo; GRINOVER, Ada Pellegrini; DINAMARCO, Cândido Rangel. Teoria geral do processo. $27^{\mathrm{a}}$ ed. São Paulo: Malheiros, 2011, p. 25.

${ }^{75}$ Idem. p. 26. 
Miguel Reale, além de se posicionar nesse sentido, explica que também não há como existir atividade social sem que ali esteja presente o Direito.

Podemos, pois, dizer, sem maiores indagações, que o Direito corresponde à exigência essencial e indeclinável de uma convivência ordenada, pois nenhuma sociedade poderia subsistir sem um mínimo de ordem, de direção e solidariedade. É a razão pela qual um grande jurista contemporâneo, Santi Romano, cansado de ver o Direito concebido apenas como regra ou comando, concebeu-o antes como "realização de convivência ordenada".

De "experiência jurídica", em verdade, só podemos falar onde e quando se formam as relações entre os homens, por isso denominadas relações intersubjetivas, por envolverem sempre dois ou mais sujeitos. Daí a sempre nova lição de um antigo brocado: ubi societas, ibi jus (onde está a sociedade, está o Direito). A recíproca também é verdadeira: ubi jus, ibi societas, não se podendo conceber qualquer atividade social desprovida de forma e garantia jurídicas, nem qualquer regra jurídica que não se refira à sociedade. ${ }^{76}$

Ao concluir que não existe sociedade sem Direito, tampouco Direito sem sociedade, torna-se possível verificar que, nessa estreita correlação, os avanços em qualquer um dos segmentos modificarão, por consequência, o outro.

Analisando a história da humanidade e, em especial, a do Direito, constata-se que apenas uma classe seleta e mínima de pensadores enxergaram à frente de seu tempo, prevendo novas situações que poderiam surgir e necessitariam de solução jurídica. Entre eles, destaca-se Emmanuel-Joseph Sieyès, pensador francês que, já na primeira Assembleia Nacional Constituinte francesa, quando ainda se discutia sua primeira Constituição escrita e cujo objetivo principal era limitar o então poder

${ }^{76}$ REALE, Miguel. Lições preliminares de Direito. $27^{\mathrm{a}}$ ed. São Paulo: Saraiva, 2009, p. 2. 
absoluto do rei para constituir uma nova França, previa a necessidade da criação de mecanismos para o controle das futuras modificações do texto constitucional. ${ }^{77}$

Porém, esses poucos seletos, assim como Sieyès, raramente conseguiam ser ouvidos pela maioria de seus pares, tendo as suas importantes contribuições sido reconhecidas, posteriormente, apenas por seus sucessores.

Isso confere razão à regra de que a modificação do Direito acontece após e em função das transformações sociais. Tanto é assim que há previsão, na legislação brasileira, como, por exemplo, na Lei de Introdução às Normas do Direito Brasileiro, ${ }^{78} \mathrm{em}$ seu artigo $4^{\circ}$, de outros institutos jurídicos diversos da lei, visando à solução de conflitos, sem previsão normativa, como a analogia, os costumes e os princípios gerais do direito.

As transformações percebidas na sociedade, sejam de seus costumes ou conceitos, ou até mesmo aquelas impostas por fenômenos naturais, entre tantos outros fatores que a modificam, são a mola propulsora da evolução do Direito, o qual, na sua essência, deve ser compreendido como um processo de adaptação social, como destaca Paulo Nader.

As instituições jurídicas são inventos humanos que sofrem variações no tempo e no espaço. Como processo de adaptação social, o Direito deve estar sempre se refazendo, em face da mobilidade social. A necessidade de ordem, paz, segurança, justiça, que o Direito visa a atender, exige procedimentos sempre novos. Se o Direito se envelhece, deixa de ser um processo de adaptação, pois passa a não exercer a função para a qual foi criado. Não basta, portanto, o ser do Direito na sociedade, é indispensável o ser atuante, o ser atualizado. Os processos de adaptação devem-se renovar, pois somente assim o Direito será

\footnotetext{
77 BARROS, Sérgio Resende de. Noções sobre poder constituinte. Disponível no site: <http://www.srbarros.com.br/pt/nocoes-sobre-poder-constituinte.cont $>$, p. 3-4. Acesso em 02/08/2015.
}

${ }^{78}$ Decreto-lei $n^{\circ} \mathbf{4 . 6 5 7}$, de 4 de setembro de 1942 , com redação dada pela Lei $\mathrm{n}^{\circ}$ $12.376 / 10$. 
um instrumento eficaz na garantia do equilíbrio e da harmonia social. $^{79}$

O ser humano, embora seja de sua natureza a curiosidade pelo desconhecido, demonstra grande insegurança diante do novo, daquilo que não tem o pleno domínio. No mundo jurídico não é diferente. No entanto, como visto, neste as mudanças são inevitáveis, momento em que surge a necessidade de se adequar às regras básicas para o convívio em sociedade, com as novas formas de pensamento e entendimento. É por isso que temas que outrora tiveram grande relevância, hoje já não mais a têm.

Por outro lado, nem sempre se está preparado para as alterações daquilo de que já se tem o pleno controle e conhecimento, porquanto a insegurança e a incerteza não são dois dos adjetivos mais admirados pela sociedade, principalmente em matéria jurídica.

Diante disso, um dos temas mais comentados na atualidade é justamente a segurança jurídica, consagrada pela disposição constitucional que veda a alteração da coisa julgada, isto é, fatos que já foram analisados pelo Poder Judiciário, em regra, não mais comportam discussão.

Essa preocupação foi expressa claramente na Constituição da República do Brasil, especificamente, em seu artigo $5^{\circ}$, inciso XXXVI, ao afirmar que "a lei não prejudicará o direito adquirido, o ato jurídico perfeito e a coisa julgada".

Analisando essa regra constitucional isoladamente, poder-se-ia ter a impressão de que a edição de uma nova lei produziria efeitos jurídicos apenas aos fatos futuros à sua publicação.

Contudo, tratando-se de norma penal, assim está disposto na Constituição Federal brasileira, em seu artigo $5^{\circ}$, inciso XL: "a lei penal não retroagirá, salvo para beneficiar o réu".

Está, portanto, consagrado na Constituição Federal o princípio da retroatividade da lei mais benéfica, também conhecido como favor rei, que prescreve a extra-atividade da lex mitior, isto é, a aplicação da lei posterior àquela vigente no momento da prática da infração penal quando esta tolha o caráter delituoso do fato ou contenha dispositivos mais favoráveis ao agente.

${ }^{79}$ NADER, Paulo. Introdução ao estudo do Direito. 33 $3^{\mathrm{a}}$ ed. Rio de Janeiro: Forense, 2011, p. 19. 
Logo, em matéria penal, uma simples modificação legislativa pode trazer consequências e alterações em entendimentos doutrinário e jurisprudencial já consolidados, promovendo a rediscussão de casos já decididos, nos quais, por vezes, o próprio condenado já poderia ter cumprido parcial ou integramente uma pena privativa de liberdade que lhe havia sido imposta.

A Lei Federal $n^{\circ} 12.015$, de 7 de agosto de 2009, trouxe profundas modificações nas condutas tipificadas como crimes sexuais, particularmente, nos delitos sexuais violentos, isto é, aqueles de conotação sexual cometidos mediante o emprego de violência ou grave ameaça.

Anteriormente à publicação da citada lei, havia, no ordenamento jurídico-penal brasileiro vigente, dois delitos dessa natureza, cometidos mediante violência ou grave ameaça: estupro e atentado violento ao pudor, previstos, respectivamente, nos artigos 213 e 214 do Código Penal.

Após uma leitura preliminar e comparativa desses tipos penais com o novo texto legal, ter-se-ia a impressão de que o propósito do legislador brasileiro, ao editar essa norma penal, seria conferir maior rigor à punição prevista em abstrato para os delitos dessa espécie, principalmente pela análise das qualificadoras que agora integram os parágrafos $1^{\circ}$ e $2^{\circ}$ do artigo 213 do Código Penal, com a redação que lhes foi dada pela Lei $\mathrm{n}^{\mathrm{o}} 12.015 / 09$. Contudo, pode em verdade não ter ocorrido isso. Ao contrário, como se diz no jargão popular: "O tiro saiu pela culatra!"

O legislador reformador unificou as condutas anteriormente tipificadas como crimes de estupro e atentado violento ao pudor em um único tipo legal, previsto agora no artigo 213 do Código Penal, denominado tão somente de estupro.

A união dessas duas condutas no tipo penal do artigo 213 do codex em questão trouxe relevantes alterações no âmbito do direito penal, já que o novo delito de estupro passou a ser classificado por muitos estudiosos dessa seara como "crime único".

As consequências dessas alterações são muitas e profundas, tanto em relação aos casos que já haviam sido julgados em definitivo pelo Poder Judiciário, como para as futuras práticas delituosas, conforme já mencionado.

Observa-se, desta feita, que a publicação de uma nova lei penal que promove alterações substanciais no ordenamento jurídico respectivo traz grandes incertezas quanto a sua adequada interpretação e aplicação, fazendo surgir muitas controvérsias e divergências em matéria de Direito, 
dada a sua evidente subjetividade. Diante disso, apontar tais dúvidas e divergências, bem como as possíveis soluções para as mesmas, utilizando-se, para tanto, das regras e dos princípios gerais do direito penal em vigência, é de grande valia e relevância.

Nesse contexto, inobstante o estudo contemporâneo das novas normas editadas, a análise histórica dos tipos penais é de extrema importância, pois a revogação de uma lei, no âmbito do direito penal, não significa necessariamente a sua exclusão imediata do ordenamento jurídico.

Com efeito, toda ciência jurídica, assim como qualquer outra, não é o resultado do trabalho e da pesquisa isolados de uma geração. Ao contrário, consubstancia-se num patrimônio científico, "pois corresponde à soma das experiências vividas no passado e no presente. As conquistas científicas de hoje são acréscimos ao trabalho de ontem", ${ }^{80}$ seja criticando-o para a formulação de uma nova teoria ou simplesmente buscando a evolução do pensamento anterior.

Por isso, de fato "é impossível dissociar o Direito da História: ambos caminham juntos, interligados, entrelaçados pelas mais variadas mutações da vida em sociedade". ${ }^{81}$

Para se compreender uma norma jurídica, que representa a soma de todas as suas precursoras e de todas as transformações da sociedade, mister o estudo da evolução histórica, tanto da norma como da sociedade.

No Brasil, entretanto, como adverte Vladimir Passos de Freitas, "a história do Direito ainda é pouco estudada", sendo raros "os congressos, as dissertações de mestrado e as teses de doutorado na área". ${ }^{82}$

$\mathrm{Na}$ prática, também em especial no âmbito do direito penal, pouco se vê de discussões proveitosas, ou seja, falta uma dialética jurídica para a unificação da jurisprudência pátria. Os precedentes judiciários são utilizados caso interessem às partes e pouco contestados, com exceção daqueles que se dedicam a tal no mundo acadêmico. Com efeito, chama a atenção o dissenso em matéria penal no Superior Tribunal de Justiça pátrio. Encontrar decisões similares entre as $5^{\mathrm{a}}$ e $6^{\mathrm{a}}$ Turmas, por exemplo,

${ }^{80}$ NADER, Paulo. Introdução ao estudo do Direito. $33^{\mathrm{a}}$ ed. Rio de Janeiro: Forense, 2011. p. 13.

${ }^{81}$ ROLIM, Luiz Antonio. Instituições de direito romano. $4^{\text {a }}$ ed. São Paulo: Revista dos Tribunais, 2010, p. 29.

82 FREITAS, Vladimir Passos de. No Brasil, a história do Direito ainda é pouco estudada. Disponível no site: <http://www.conjur.com.br/2010-jun-28/segunda-leitura-brasilhistoria-direito-estudada>, p. 1 . Acesso em 08/08/2015. 
torna-se um dos afazeres mais difíceis, pois o que impera é o antagonismo. Não que isto não seja bom, já que também tem o seu lado positivo por expressar os fundamentos da democracia e independência dos juízes. $\mathrm{O}$ que incomoda na verdade é a percepção de que pouco se tem discutido e avançado para unificar o entendimento jurisprudencial. A Acusação, valendo-se dos precedentes da $5^{a}$ Turma do referido Tribunal Superior, limita-se apenas em neles fundamentar os seus pedidos, ignorando os julgados da $6^{\text {a }}$ Turma. Já a Defesa faz exatamente o contrário. A sensação, enfim é a de que não se fala de um Tribunal Superior, mas sim de dois.

Diante de tal situação, é imperioso verificar que muitos daqueles que recorrem ao referido Tribunal Superior, seja pela Acusação, seja pela Defesa, já não têm mais a preocupação de se empenhar em discutir o Direito e fundamentar suas teses, limitando-se, outrossim, a torcer pela distribuição a uma de suas Turmas.

Entretanto, urge destacar a necessidade e a importância de se proceder a uma reanálise da racionalidade legislativa no ordenamento jurídico-penal brasileiro, haja vista o direito penal ter assumido e acumulado, frente às diversas falências sóciojurídicas do Estado, relevantes funções sociais que até então não lhe eram peculiares ou naturais, transmutando-se, desta forma, a função jurídica do Código Penal em subterfúgio último para a manutenção e reafirmação da combalida moral social; em suma, um verdadeiro "Código da Moral". ${ }^{83}$

E tamanha é a irracionalidade legislativa brasileira relativa à criação de tipos penais que o Judiciário acaba tendo o ônus de interpretar sistematicamente as normas dessa natureza, o que desemboca, muitas vezes, em visões diferentes sobre um mesmo fato. Certamente, esse fato alimenta a existência do citado antagonismo nas Turmas do Superior Tribunal de Justiça.

Nesse diapasão, tendo em vista o direito penal assumir tão relevante função social no mundo fenomênico, fundamental é que ele retorne à sociedade proporcional resposta ao que do mesmo se espera, mostrando-se, portanto, imperiosa a necessidade de que esse ramo do direito reflita a própria racionalidade e necessidade sociais por meio de leis, as quais, da mesma forma, sejam fruto de um processo racional de construção.

${ }^{83}$ DÍEZ RIPOLLÉS, José Luiz. La racionalidad de las leyes penales. Madrid: Trotta, 2003, p. 14. 
Todavia, insta frisar que não se trata de uma crítica pura e simples, já que, em um Estado Social e Democrático de Direito, o antagonismo de ideias e pensamentos é natural, especialmente no universo jurídico. Trata-se, pois, de uma constatação realizada para fundamentar a necessidade do estudo histórico e da evolução dos tipos penais no ordenamento jurídico brasileiro, a fim de que se possa chegar a um resultado possível de ser considerado satisfatório, mas à luz dos direitos que fundamentam esse mesmo Estado de Direito.

Diante disso, para uma melhor interpretação da norma penal, visando-se a alcançar aquele resultado, vale registrar a lição de René Ariel Dotti, para quem "o 'elemento histórico' permite conhecer melhor a norma em função das condições e das circunstâncias que, no passado, determinaram a sua elaboração". ${ }^{84}$

\section{APONTAMENTOS SOBRE A EVOLUÇÃO HISTÓRICA DO DELITO DE ESTUPRO NO ORDENAMENTO JURÍDICO-PENAL BRASILEIRO}

O direito penal antigo, antes da promulgação do Código Criminal do Império, de 1830, isto é, durante o período colonial brasileiro, consubstanciava-se na aplicação efetiva da legislação estrangeira, ${ }^{85}$ imperante no território nacional até então. Tratavam-se dos 143 Títulos do Livro V das Ordenações Filipinas, também denominadas de Código Filipino.

Embora nas Ordenações Filipinas não tivesse sido utilizada a rubrica "estupro", já havia previsão legal para a conduta delitiva de praticar conjunção carnal "per força", a qual era punida com a pena de morte, ainda que o autor se casasse com a vítima.

A propósito, registra-se sua descrição, no Título XVIII, do Livro V, do Código Filipino.

\footnotetext{
${ }^{84}$ DOTTI, René Ariel. Curso de direito penal: parte geral. $3^{\mathrm{a}}$ ed. São Paulo: Revista dos Tribunais, 2011, p. 252.

${ }^{85}$ Conforme explica José Salgado MARTINS, as Ordenações Filipinas não são portuguesas e nem brasileiras. Foram promulgadas por um monarca espanhol em 11 de janeiro de 1603 (Filipe III, na Espanha, ou Filipe II, quando rei em Portugal) e, aqui, no Brasil, vigoraram até 16 de dezembro de 1830. In: Sistema de direito penal brasileiro. Rio de Janeiro: José Konfino, 1967. p. 94-95.
} 
Do que dorme per força com qualquer mulher, ou trava della, ou a leva per sua vontade.

Todo homem, de qualquer stado e condição que seja, que forçosamente dormir com qualquer mulher postoque ganhe dinheiro per seu corpo, ou seja scrava, morra por ello.

(...)

1. E postoque o forçador depois do malefício feito case com a mulher forçada, e aindaque o casamento seja feito per vontade della, não será relevado da dita pena, mas morrerá, assi como se com ella não houvesse casado. ${ }^{86}$

Registra Nélson Hungria que, "desde os mais antigos tempos e entre quase todos os povos, a conjunção carnal violenta foi penalmente reprimida como grave malefício". ${ }^{87} \mathrm{Na}$ primeira lei penal efetivamente aplicada no Brasil - as Ordenações Filipinas -, conforme se pode observar pela transcrição do Título XVIII, do Livro V, não era diferente. Na punição do crime de conjunção carnal violenta, que posteriormente veio a ser conhecido pela denominação de estupro, existia grande rigor, o qual se refletia na sua pena, que era a capital, subsistindo mesmo no caso de casamento entre autor e vítima. No entanto, tamanha severidade com o crime de estupro não era estranha para a época; na verdade, esse era o tratamento punitivo normal para quase todos os delicta carnis, ${ }^{88}$ o qual se estendia, na verdade, a vários outros crimes. ${ }^{89}$

${ }^{86}$ Apud PIERANGELli, José Henrique. Códigos penais do Brasil. Evolução histórica. Bauru/SP: Javoli, 1980, p. 29. Ortografia original.

${ }^{87}$ HOFFBAUER, Nélson Hungria; LACERDA, Romão Côrtes de. Comentários ao código penal, v. VIII. $4^{\text {a }}$ ed. Rio de Janeiro: Forense, 1959, p. 114.

${ }^{88}$ Cf. nesse sentido: Títulos XIII (Dos que commettem peccado de sodomia, e com alimárias), XIV (Do Infiel, que dorme com alguma Christã, e do Christão, que dorme com Infiel), XV (Do que entra em Mosteiro, ou tira Freira, ou dorme com ella, ou a recolhe em casa), XVI (Do que dorme com a mulher, que anda no Paço, ou entra em casa de alguma pessoa para dormir com mulher virgem, ou viúva honesta, ou escrava branca de guarda) e XVII (Das que dormem com suas parentas e affins). In: PIERANGELI, José Henrique. Op. cit., p. 26-28. Ortografia original.

${ }^{89}$ Acerca dessa questão, observa Heleno Cláudio FRAGOSO: “A legislação penal do Livro V era realmente terrível, o que não constitui privilégio seu, pois era assim toda a legislação penal de sua época. A morte era a pena comum e se aplicava a grande número de delitos, sendo executada muitas vezes com requintes de crueldade”. In: Lições de direito penal. $16^{\mathrm{a}}$ ed. Rio de Janeiro: Forense, 2003, p. 70. 
Com a vinda da Família Real portuguesa para o Brasil, em 1808 , e a abertura dos portos brasileiros às nações amigas, segundo previu a Carta Régia de 28 de janeiro de 1808, nenhuma mudança substancial se verificou na legislação penal em vigência à época. Na verdade, surgiram pontuais alterações após o retorno de D. João VI a Portugal, ocasião em que o Príncipe Regente, D. Pedro, legislou sobre a prisão de criminosos (Decreto de 23 de maio de 1821) e o julgamento de abusos da liberdade de imprensa (Decreto de 18 de junho de 1822). Tais mudanças, contudo, refletiram claramente no direito processual penal daquele momento histórico, e não no penal..$^{90}$

Com a proclamação da Independência e depois do advento da Constituição do Império do Brasil, mudanças significativas se avistaram para o direito penal da época, valendo destacar que o artigo 179, inciso XVIII, da Constituição de 1824, determinou a urgente e necessária elaboração de um Código Criminal "fundado nas sólidas bases da Justiça e Equidade". ${ }^{91}$

Vigente a partir de 1830, o Código Criminal do Império do Brasil foi o primeiro diploma a utilizar a rubrica "estupro" para denominar um crime, muito embora a mesma não representasse tão somente esse crime em si, isto é, conjunção carnal forçada, mas sim, outros vários delitos de conotação sexual, o que fez a doutrina da época repudiar a técnica redacional utilizada. ${ }^{92}$

O Título II, Capítulo II, Secção I, do Código Criminal brasileiro de 1830 previa, sob a mesma rubrica de "estupro", os seguintes delitos:

219);

a) defloramento de mulher virgem e menor de 16 anos (artigo

b) defloramento de mulher virgem e menor de 16 anos por quem a tem sob seu poder ou guarda (artigo 220);

\footnotetext{
${ }^{90}$ PIERANGELI, José Henrique. Op. cit., p. 8.

${ }^{91}$ Ortografia original. No que diz respeito ao referido dispositivo constitucional, importante a observação de Joaquim Augusto de CAMARGO: "De fato, o art. 179 da mesma Constituição é um manancial abundantíssimo dos princípios de justiça e equidade, reconhecidos pelo direito moderno como os únicos que devem servir de apoio às boas leis". In: Direito penal brasileiro. $2^{\text {a }}$ ed. São Paulo: Revista dos Tribunais, 2005, p. 139. 92 Cf. nesse sentido: RAMOS JUNIOR, Antonio de Paula. Commentario ao código criminal brasileiro. Rio de Janeiro: Carioca, 1875, p. 177; SIDOU, J. M. Othon. Do conceito de stuprum entre os delitos sexuais no direito romano. In: Revista da Faculdade de Direito de Caruaru/Asces, v. 1, n 1, 1960, p. 94; PRADO, Luiz Regis. Curso de direito penal brasileiro, v. 2. $7^{\text {a }}$ ed. São Paulo: Revista dos Tribunais, 2008, p. 637.
} 
c) defloramento de mulher virgem e menor de 16 anos por pessoa a ela relacionada por grau de parentesco que não admita dispensa para casamento (artigo 221);

d) cópula carnal por meio de violência ou ameaça com mulher honesta (artigo 222);

e) ofensa pessoal a mulher para fim libidinoso, causando-lhe dor ou mal corpóreo, sem que se verifique a cópula carnal (artigo 223); e

f) sedução de mulher honesta e menor de 17 anos, praticando com ela conjunção carnal (artigo 224).

Todavia, a tipificação do estupro propriamente dito, dentre esses crimes, era outra.

Art. 222. Ter cópula carnal por meio de violencia ou ameaças, com qualquer mulher honesta.

Penas - de prisão por tres a doze annos, e de dotar a offendida.

Se a violentada fôr prostituta.

Penas - de prisão por um mez a dous annos. ${ }^{93}$

Interessante também notar, que além de ter abrandado a pena de forma considerada em relação às Ordenações Filipinas, o Código Criminal do Império previu ainda a possibilidade de extinção da pena do estupro caso a ofendida se casasse com o ofensor, conforme o artigo $225 .{ }^{94}$

A derrubada da Monarquia brasileira, com o consequente nascimento da República, demandava com urgência um novo Código Penal, eis que os novos ideais republicanos já não se ajustavam a algumas disposições da época imperial.

Ainda durante o Governo provisório, presidido pelo Marechal Deodoro da Fonseca, o então Ministro da Justiça, Campos Salles, incumbiu a João Batista Pereira, que antes mesmo da proclamação da República já vinha trabalhando em um novo Projeto de Código Penal, a tarefa de elaborá-lo. ${ }^{95}$ Contudo, este diploma legal seria cunhado por Aníbal Bruno

\footnotetext{
93 Apud PIERANGELLI, José Henrique. Op. cit., p. 243. Ortografia original.

94 “Art. 225. Não haverão as penas dos tres artigos antecedentes os réos que casarem com as offendidas”. Ibid., p. 244. Ortografia original.

95 Ibid., p. 10.
} 
de "menos feliz que o seu antecessor", tamanha "a pressa com que foi concluído". 96

A despeito das críticas que lhe foram feitas à época, imperioso é reconhecer que, quanto ao crime de estupro, o Código Penal de 1890 representou um grande marco no âmbito do direito penal brasileiro. Com efeito, sob sua égide a denominação "estupro" foi consagrada e restrita à prática da conjunção carnal, mediante violência ou grave ameaça.

O estatuto repressivo em questão dispunha sobre o crime de estupro no Título VIII, Capítulo I, da seguinte forma a seguir descrita.

Da violencia carnal.

(...)

Art. 268. Estuprar mulher virgem ou não, mas honesta:

Pena - de prisão cellular por um a seis annos.

$\S 1 .^{\circ}$ Se a estuprada fôr mulher publica ou prostituta:

Pena - de prisão cellular por seis meses a dois annos. $\S 2 .^{\circ}$ Se o crime fôr praticado com o concurso de duas ou mais pessoas, a pena será augmentada da quarta parte.

Art. 269. Chama-se estupro o acto pelo qual o homem abusa, com violencia, de uma mulher, seja virgem ou não. Por violencia entende-se não só o emprego da força physica, como o de meios que privarem a mulher de suas faculdades psychicas, e assim da possibilidade de resistir e defender-se, como sejam o hypnotismo, o chloroformio, o ether, e, em geral, os anesthesicos e narcoticos. ${ }^{97}$

Nota-se, portanto, que o Código Penal de 1890 restringiu à tipificação de estupro apenas a violência (abuso) carnal contra mulher, esclarecendo no tipo penal explicativo contido no artigo 269 os conceitos de estupro e violência para fins desse delito. ${ }^{98}$

\footnotetext{
${ }^{96}$ BRUNO, Aníbal. Direito penal, parte geral - tomo I. $5^{\text {a }}$ ed. Rio de Janeiro: Forense, 2005 , p. 104.

${ }^{97}$ Apud PIERANGELLI, José Henrique. Op. cit., p. 299. Ortografia original.

${ }^{98}$ Relativamente a esses tipos penais explicativos, Chrysolito de GUSMÃO registra suas críticas sobre a atitude que o legislador teve no sentido de não apenas descrever os elementos componentes do crime de estupro, mas de ir além, para definir o que entendia por
} 
Além disso, vale destacar que o Código Republicano, seguindo a tendência da evolução do direito penal, tal como já havia ocorrido com as Ordenações Filipinas em relação ao Código Criminal do Império, cominou pena mais branda que os diplomas anteriores, isto é, previu uma punição com prisão celular, de um a seis anos.

Em razão dos defeitos e das críticas feitas ao Código Penal da República do Brasil de 1890, conforme já mencionado, surgiram vários projetos para substituí-lo. Contudo, o código em questão não foi substituído na íntegra com o passar dos anos, mas sim, profundamente alterado e acrescido de várias leis penais extravagantes, com o objetivo de completá-lo. Foi este o motivo da Consolidação das Leis Penais de 1932, de acordo com René Ariel Dotti.

A natural profusão de leis durante o período republicano e as tendências muito vivas no sentido de se rever o CP de 1890 levaram o Governo a promover uma consolidação das leis existentes. Havia dificuldades não somente de aplicação das leis extravagantes, como também de seu próprio conhecimento.

Na Exposição de Motivos do Decreto $\mathrm{n}^{\circ}$ 22.213, de 14.12.1932, o Chefe do Governo Provisório admitia o malogro das várias tentativas de reforma do Código Penal brasileiro "que ora se empreende e ainda tardará em ser convertida em lei, não obstante a dedicação e competência da respectiva Subcomissão Legislativa”.

violência. Tal atitude, para o autor, limitou a atuação da doutrina e da jurisprudência para a construção da técnica e exegese do texto, além do que o legislador o fez "da forma mais desastrosa, a mais imperfeita, revelando (...) ou um descaso absoluto ou um pasmoso desconhecimento da tecnologia jurídica, sendo levado (...) a fechar as portas de saída do círculo fechado em que encerrou o delito e dando (...) lugar às terríveis dificuldades que seremos forçados a patentear (...). Nosso legislador, que após prefigurar e punir o crime de estupro no art. 268, foi (...) mais além, tendo no art. 269 afastado toda e qualquer veleidade do exegeta para, não só definir, formal e expressamente, o que considerava crime de estupro, como, outrossim, na segunda parte do mesmo art. 269 definiu o que compreendia por violência”. In: Dos crimes sexuais. $6^{\text {a }}$ ed. Rio de Janeiro: Freitas Bastos, 2001, p. 88 e 103. 
O trabalho de consolidação foi realizado pelo Desembargador Vicente Piragibe e continha 410 artigos. Nos termos do decreto de promulgação, o diploma aprovado não revogava dispositivo da lei em vigor no caso de incompatibilidade entre os textos respectivos (art. $1^{\circ}$, parágrafo único).$^{99}$

Quanto ao delito de estupro, nenhuma alteração foi feita entre o Código Penal de 1890 e a Consolidação das Leis Penais de 1932. Com efeito, sequer a numeração do artigo foi alterada, sendo que a única diferença verificável entre esses dois diplomas se resume a algumas pequenas atualizações ortográficas feitas na redação da Consolidação. Basta, para isso, constatar o seu teor.

Da violencia carnal.

(...)

Art. 268. Estuprar mulher virgem ou não, mas honesta:

Pena - de prisão cellular por um a seis annos.

$\S 1 .^{\circ} \mathrm{Si}$ a estuprada fôr mulher publica ou prostituta:

Pena - de prisão cellular por seis mezes a dois annos.

$\S 2 .^{\circ}$ Si o crime fôr praticado com o concurso de duas ou mais pessoas, a pena será augmentada da quarta parte.

Art. 269. Chama-se estupro o acto pelo qual o homem abusa com violencia de uma mulher, seja virgem ou não. Por violencia entende-se não só o emprego da força physica, como o de meios que privarem a mulher de suas faculdades psychicas, e assim da possibilidade de resistir e defender-se, como sejam o hypnotismo, o chloroformio, o ether, e, em geral, os anesthesicos e narcóticos. ${ }^{100}$

Dentre os projetos de reforma penal que foram propostos após o Código Penal de 1890, o primeiro estatuto repressivo da República, o

\footnotetext{
${ }^{99}$ DOTTI, René Ariel. Op. cit., 2003, p. 196.

${ }^{100}$ PIERANGELI, José Henrique. Op. cit., p. 373.
} 
Projeto do Código Criminal brasileiro, de autoria do Professor Alcântara Machado e precursor do Código Penal de 1940, constitui, sem prejuízo de visão contrária, o principal deles, em razão da sua linguagem, originalidade, técnica e estrutura. ${ }^{101}$

O papel exercido por Alcântara Machado no cenário político do País, acompanhado de acontecimentos marcantes em nível nacional, foi decisivo para apontar o rumo a ser seguido pela legislação penal pátria. Dono de linguajar e escrita impecáveis, ele apresentou à comissão que o havia designado para a tarefa um projeto que identificava pontos de semelhança com o até então Código Penal de 1890, devendo-se ao fato de ambos terem se inspirado nos modelos italiano e suíço. Porém, seu projeto possuía mais originalidade e técnica mais apurada. Mas, como observa Basileu Garcia, apesar de notável a "larga e preciosa contribuição do Professor Alcântara Machado,"102 são reconhecidas muitas mudanças substanciais feitas pela comissão revisora, a ponto de Galdino Siqueira qualificá-lo não apenas como uma revisão, mas um "outro projeto". ${ }^{103}$

O projeto final, segundo Nélson Hungria - a quem costumeiramente é atribuída a autoria do Código Penal -, também utilizou pontos específicos dos códigos penais suíço, dinamarquês e polonês, além do projeto anteriormente ofertado por Virgílio de Sá Pereira, em 1927. ${ }^{104}$

Esse projeto - então definitivo - foi entregue pela comissão revisora em 4 de novembro de 1940 e sancionado em 7 de dezembro do mesmo ano, pelo Decreto-lei $n^{\circ} 2.848$, mas entrou em vigência somente no dia 1 de janeiro de 1942.

${ }^{101}$ É provável que a escolha de Machado se deu por ser ele um intelectual tradicional originário da região do Brasil de maior desenvolvimento econômico e incomensurável peso político, que poderia transformá-lo em excelente auxiliar do governo, no âmbito da mais respeitada corporação jurídica do País - Faculdade de Direito da USP. Nesse sentido: ALVES, Eliete. Alcântara Machado: um perfil do intelectual e político paulista e o projeto do código criminal brasileiro (1937/42). Dissertação de Mestrado. São Paulo: Pontifícia Universidade Católica de São Paulo, 1989, p. 6.

102 GARCIA, Basileu. Instituições de direito penal, v. 1, t. 1. $4^{\mathrm{a}}$ ed. São Paulo: Max Limonad, 1973, p. 127.

103 SIQUEIRA, Galdino. Tratado de direito penal: parte geral, t. 1. São Paulo: José Konfino, 1947, p. 80.

${ }^{104}$ HOFFBAUER, Nélson Hungria. A autoria intelectual do Código Penal de 1940. In: Conferência pronunciada na Faculdade Livre de Direito do Rio de Janeiro, 1954, Rio de Janeiro. 
O delito de estupro no Código Penal de 1940 surgiu inserido no Título VI, Capítulo I, contendo a seguinte redação original: "Art. 213. Constranger mulher à conjunção carnal, mediante violência ou grave ameaça: Pena - reclusão, de três a oito anos".

Com a elaboração do Código Penal de 1969, pelo mesmo Nélson Hungria, a previsão do delito de estupro se manteve no Título VI, Capítulo I, com idêntica redação e mesma quantidade de pena privativa de liberdade, a saber: "Art. 238. Constranger mulher à conjunção carnal, mediante violência ou grave ameaça: Pena - reclusão, de três a oito anos". No entanto, este código nunca chegou a entrar em vigência no território brasileiro, tendo sido definitivamente revogado pela Lei $\mathrm{n}^{\circ}$ 6.578, de 11 de outubro de 1978.

Mantida a vigência do Código Penal de 1940, a primeira alteração realizada no tipo penal do estupro aconteceu em 13 de julho de 1990 e foi promovida pela Lei Federal $n^{\circ} 8.069$, conhecida como Estatuto da Criança e do Adolescente, que inseriu um parágrafo único no artigo 213, com esta redação: "Art. 213. (...) Parágrafo único. Se a ofendida é menor de catorze anos: Pena - reclusão, de quatro a dez anos".

Em seguida, a Lei Federal n ${ }^{\circ}$ 8.072, de 25 de julho de 1990, conhecida como Lei dos Crimes Hediondos, alterou o preceito secundário do caput do artigo 213, com a nova redação: "Art. 213. Constranger mulher à conjunção carnal, mediante violência ou grave ameaça: Pena reclusão, de seis a dez anos".

Finalmente, a Lei Federal n ${ }^{\circ}$ 9.281, de 4 de junho de 1996, revogou expressamente o parágrafo único do artigo 213, que ficou com a redação a seguir: "Art. 213. Constranger mulher à conjunção carnal, mediante violência ou grave ameaça: Pena - reclusão, de seis a dez anos".

Com isso, distinguia-se claramente no referido diploma repressivo os delitos de estupro e atentado violento ao pudor, ambos considerados crimes contra os costumes, particularmente crimes contra a liberdade sexual, dispostos, respectivamente, nos artigos 213 e 214. Além disso, havia previsão legal de duas qualificadoras, quais sejam violência com resultado lesão corporal de natureza grave e violência com resultado morte (artigo 223, caput e parágrafo único), e da chamada presunção de violência nesses delitos sexuais, contida no artigo 224 do Código Penal. Assim permaneceu o regramento penal do delito de estupro, até o advento da Lei $\mathrm{n}^{\circ} 12.015$, de 7 de agosto de 2009. 


\section{ESTRUTURA TÍPICA ATUAL DO DELITO DE ESTUPRO: QUESTÕES CONTROVERTIDAS SOB A ÓTICA DOS PRINCÍPIOS CONSTITUCIONAIS}

A Lei $n^{\circ}$ 12.015/09 promoveu importantes alterações no Código Penal brasileiro, datado de 1940, naquilo que diz respeito aos delitos sexuais, a começar pela própria nomenclatura desses delitos. A partir de então, as condutas tipificadas no Título VI do citado Código não configuram mais "crimes contra os costumes"; constituem, outrossim, "crimes contra a dignidade sexual", espécies do gênero "dignidade da pessoa humana", compreendida esta, por sua vez, como um conjunto de garantias positivas e negativas. ${ }^{105}$

Divergem opiniões entre os estudiosos do direito penal quanto à opção terminológica utilizada, identificando como bem jurídico-penal tutelado a dignidade sexual do ser humano. Guilherme de Souza Nucci defende a nova nomenclatura, entendendo que a anterior se achava inadequada, porquanto lastreada em modelos de observação comportamental da sexualidade na sociedade em geral, ocasião em que os "costumes" representavam visão vetusta dos hábitos medianos e até mesmo puritanos da moral vigente, inexistindo critérios a estabelecer parâmetros comuns e denominadores abrangentes a nortear o foco dos "costumes" na sociedade brasileira. $^{106}$

Cezar Roberto Bitencourt registra que o antigo título era impróprio, na medida em que não correspondia aos bens jurídicos que o mesmo pretendia tutelar, ${ }^{107}$ ao passo que Julio Fabbrini Mirabete frisa que o legislador de 2009 eliminou anacronismos existentes até então, oriundos de preconceitos e moralismos arraigados na sociedade à época da elaboração

\footnotetext{
105 Nesse sentido, Antonio Enrique PÉREZ LUÑO: "La dignidad humana constituye no sólo la garantía negativa de que la persona no va a ser objeto de ofensas o humillaciones, sino que entraña también la afirmación positiva del pleno desarrollo de la personalidad de cada individuo. El pleno desarrollo de la personalidad supone, a su vez, de un lado, el reconocimiento de la total autodisponibilidad, sin interferencias o impedimentos externos, de las posibilidades de actuación proprias de cada hombre; de otro, la autodeterminación (Selbstbestimmung des Menschen) que surge de la libre proyección histórica de la razón humana, antes que de una predeterminación dada por la naturaleza”. In: Derechos humanos, estado de derecho y constitución. $9^{\text {a }}$ ed. Madrid: Tecnos, 2005, p. 324.

106 NUCCI, Guilherme de Souza. Crimes contra a dignidade sexual: comentários à Lei 12.015, de 7 de agosto de 2009. São Paulo: Revista dos Tribunais, 2009, p. 16-18.

${ }^{107}$ BITENCOURT, Cezar Roberto. Tratado de direito penal: parte especial, v. 4. $5^{\mathrm{a}}$ ed. São Paulo: Saraiva, 2011, p. 37.
} 
do Código Penal ora vigente. ${ }^{108}$ Rogério Greco arremata, enfim, que com a modificação legislativa, percebeu-se que o foco de proteção já não era mais a forma como as pessoas deveriam se comportar sexualmente perante a sociedade do século XXI, mas sim a tutela da sua dignidade sexual. ${ }^{109}$

Por outro lado, ao fazer seus comentários acerca do título referente aos "crimes contra os costumes", Alberto Silva Franco demonstra sua contrariedade à (atual) expressão "crimes contra a dignidade sexual". Assevera, entre outras coisas, que

em matéria de sexualidade enquanto componente inafastável do ser humano, não se cuida de sexo digno ou indigno, mas tão-somente de sexo realizado com liberdade ou sexo posto em prática mediante violência ou coação, ou seja, com um nível maior ou menor de ofensa à autodeterminação sexual do parceiro. Destarte, toda lesão à liberdade sexual da pessoa humana encontra seu núcleo na falta de consensualidade. Fora daí não há conduta sexual que deva ser objeto de consideração na área penal. ${ }^{110}$

No direito positivo brasileiro a dignidade ocupa posição de destaque. A Constituição de 1988 aponta a dignidade do ser humano como sendo fundamento do próprio Estado Democrático de Direito (art. $1^{\circ}, \mathrm{III}$ ), que se proclama "destinado a assegurar o exercício dos direitos sociais e individuais, a liberdade, a segurança, o bem-estar, o desenvolvimento, a igualdade e a justiça como valores supremos". Logo, o constituinte pátrio considera a dignidade humana como "valor dos valores", em torno do qual gravitam todos os demais, que devem operar em função dele.

Se, por um lado, a alteração do nomen iuris do Título VI do Código Penal brasileiro vem ao encontro do referido fundamento estatal, de outro, identifica de forma ampla a tutela jurídico-penal pretendida, ou seja, o desenvolvimento da personalidade sob o aspecto sexual, respeitan-

\footnotetext{
108 MIRABETE, Julio Fabbrini. Manual de direito penal: parte especial, v. 2. $28^{\mathrm{a}}$ ed. São Paulo: Atlas, 2011, p. 384.

${ }^{109}$ GRECO, Rogério. Curso de direito penal: parte especial, v. 3. $8^{\mathrm{a}}$ ed. Rio de Janeiro: Impetus, 2011, p. 449.

${ }^{110}$ FRANCO, Alberto Silva et. al. Código penal e sua interpretação jurisprudencial, v. 1, t. 2. $6^{\text {a }}$ ed. São Paulo: Revista dos Tribunais, 1997, p. 1.018-1.019.
} 
do-se a autodisciplina e a autodeterminação humanas. Muito embora determinadas violações sexuais tipificadas em seus dispositivos representem, ainda, uma afronta aos "costumes", na medida em que se consubstanciam em hábitos socialmente inaceitáveis, ${ }^{111}$ a alteração é positiva, pois com a opção terminológica de conteúdo semântico abrangente (crimes contra a "dignidade sexual") é possível se extrair do mesmo o significado de outros bens jurídicos, como, por exemplo, a liberdade sexual, a intimidade sexual e o desenvolvimento sexual do indivíduo. ${ }^{12}$

Inserido no Título VI e classificado como "crime contra a dignidade sexual", o delito de estupro permaneceu tipificado no artigo 213, no Capítulo I, sob a mesma nomenclatura anterior, isto é, considerado um "crime contra a liberdade sexual".

Inobstante essa observação, a Lei n ${ }^{\circ}$ 12.015/09 revogou o artigo 214 do Código Penal, ${ }^{113}$ que tipificava a conduta do atentado violento ao pudor, o qual, embora fosse considerado do mesmo gênero que o crime de estupro, diferenciava-se na espécie, na medida em que implicava a prática ativa ou omissiva de qualquer ato libidinoso diverso da conjunção carnal, em virtude de esta última já ter sido descrita anteriormente no artigo 213.

Outra alteração promovida pela novel lei penal consistiu na supressão do artigo 224 do Código Penal, ${ }^{114}$ sob cuja redação se presumia a violência da conduta do agente, consubstanciada aquela em um dos elementos necessários para sua subsunção ao tipo do estupro, diante de certas circunstâncias em que se encontrava o sujeito passivo quando da prática libidinosa, em particular, quando a vítima não era maior de 14 (catorze) anos.

Embora a pena privativa de liberdade da modalidade básica do delito tenha sido mantida a mesma, ou seja, de 6 (seis) a 10 (dez) anos de reclusão, houve fusão daquelas duas condutas até então previstas em dis-

\footnotetext{
111 Cf. nesse sentido: MARCÃO, Renato; GENTIL, Plínio. Crimes contra a dignidade sexual: comentários ao Título VI do Código Penal. São Paulo: Saraiva, 2011, p. 35.

112 Cf. nesse sentido: GRECO, Alessandra Orcesi Pedro; RASSI, João Daniel. Crimes contra a dignidade sexual. São Paulo: Atlas, 2010, p. 63.

113 "Art. 214. Constranger alguém, mediante violência ou grave ameaça, a praticar ou permitir que com ele se pratique ato libidinoso diverso da conjunção carnal: Pena - reclusão, de 6 (seis) a 10 (dez) anos".

114 “Art. 224. Presume-se a violência, se a vítima: a) não é maior de 14 (catorze) anos; b) é alienada ou débil mental, e o agente conhecia esta circunstância; c) não pode, por qualquer outra causa, oferecer resistência".
} 
positivos penais distintos - estupro e atentado violento ao pudor - em uma única, contida no artigo 213, com a nomenclatura de estupro, ao mesmo tempo em que o sujeito ativo passou a ser comum também para o caso de conjunção carnal forçada.

Quanto à idade da vítima do crime contra a liberdade sexual em testilha, o parágrafo $1^{\circ}$ do artigo 213 , in fine, previu uma modalidade circunstancial qualificada, com pena privativa de liberdade de 8 (oito) a 12 (doze) anos, se ela for maior de 14 (catorze) ${ }^{115} \mathrm{e}^{116}$ menor de 18 (dezoito) anos, ao passo que, com a referida alteração legislativa, criou-se um tipo penal autônomo, contido no artigo 217-A, com pena privativa de liberdade de 8 (oito) a 15 (quinze) anos, na hipótese de a vítima não ser maior de 14 (catorze) ${ }^{117}$ na data da prática do ato libidinoso.

Diante do panorama do direito penal sexual brasileiro atual, nos termos retratados até o presente momento, a despeito da providencial e quiçá provocante oportunidade de se promover um estudo técnicojurídico sobre questões importantes dessa temática, tais como o concurso e o conflito envolvendo os referidos tipos penais, entre outras, o que ora se pretende, há que se deixar evidente e levar a efeito uma análise técnica do delito de estupro, tanto na forma básica como na modalidade especial - estupro de vulnerável -, no tocante aos elementos que os compõem, relativamente a algumas questões que geram controvérsia doutrinária e jurisprudencial referentes à matéria, e, sobretudo, sob a ótica de um direito penal constitucional.

\footnotetext{
115 Ou tiver idade igual a 14 (catorze) anos. De fato, se a vítima é violentada no dia de seu $14^{\circ}$ aniversário, pode ser aplicada a qualificadora em comento. Não se pode concordar com a tese de que, em tal hipótese, não é possível ser aplicada essa qualificadora, porque a vítima ainda não é maior de 14 (catorze) anos (Cf. nesse sentido: GOMES, Luiz Flávio; CUNHA, Rogério Sanches; MAZZUOLI, Valério de Oliveira. Comentários à reforma criminal de 2009 e à Convenção de Viena sobre o direito dos tratados. São Paulo: Revista dos Tribunais, 2009, p. 37). Ocorre que o Código Penal, em várias passagens, vale-se de expressão semelhante, a exemplo do que ocorre nos artigos 61, II, $g$ [maior de 60 (sessenta) anos] e 65, I [maior de 70 (setenta) anos], etc. No sentido favorável à aplicação dessa qualificadora quando a vítima tem 14 (catorze) anos de idade, entre outros: GRECO, Rogério, op. cit., p. 467; ESTEFAM, André. Crimes sexuais - Comentários à Lei ${ }^{\circ}$ 12.015, de 7 de agosto de 2009. São Paulo: Saraiva, 2009, p. 43; MIRABETE, Julio Fabbrini. Op. cit., p. 393.

$116 \mathrm{Na}$ verdade, consta do tipo penal em questão a conjunção alternativa "ou" e não a conjunção opositiva "e". Claro erro redacional cometido pelo legislador pátrio, o que não prejudica, de forma alguma, a aplicação da norma.

${ }^{117}$ São válidas, aqui, as mesmas observações feitas na nota $n^{\circ} 41$.
} 
Nessa toada, o estudo passa a ter sua origem na redação vigente do delito de estupro, nas formas comum e especial, respectivamente. Seguem as redações nos termos do Código Penal.

Artigo 213. Constranger alguém, mediante violência ou grave ameaça, a ter conjunção carnal ou a praticar ou permitir que com ele se pratique outro ato libidinoso:

Pena - reclusão, de 6 (seis) a 10 (dez) anos.

(...)

Artigo 217-A. Ter conjunção carnal ou praticar outro ato libidinoso com menor de 14 (catorze) anos:

Pena - reclusão, de 8 (oito) a 15 (quinze) anos.

O delito de estupro na modalidade básica identifica, na primeira parte do tipo, a conduta do agente dirigida à conjunção carnal, no sentido de penetração do pênis na vagina. Logo, tem-se por sujeitos ativo e passivo, respectiva e necessariamente, o homem e a mulher (cópula). Essa conjunção carnal ocorre com dissenso da vítima, constrangida pela violência ou grave ameaça.

Já na sua segunda parte surge a conduta - anteriormente denominada atentado violento ao pudor - (ativa) de praticar ou (passiva) de permitir que se pratique outro ato libidinoso contra a vítima, a qual, neste caso, pode ser tanto o homem como a mulher, situação que alcança, igualmente, o sujeito ativo. Tal ato deve ser levado a efeito mediante dissenso do sujeito passivo, com emprego de violência ou grave ameaça.

Praticamente todos os doutrinadores vislumbram na expressão "outro ato libidinoso" os atos de natureza sexual que não a conjunção carnal, com o fim de satisfação da libido do agente.

Todavia, a controvérsia séria que se instala é quanto à espécie de ato libidinoso que pode ou deve ser compreendida no âmbito de alcance do tipo penal em questão, na sua segunda parte.

Isso se deve ao fato de a redação imposta pela Lei $\mathrm{n}^{\circ}$ 12.015/09 ter alargado as condutas subsumíveis ao delito de estupro, de maneira a equiparar a reprovabilidade penal imputada à conjunção carnal a qualquer outro ato libidinoso, este, inclusive, por vezes, podendo ostentar reprovabilidade social sensivelmente inferior ao da conjunção carnal, irracionalidade legislativa que, além de ferir o princípio penal constitucional da 
legalidade (particularmente, na sua vertente da taxatividade ou determinação taxativa), ofende também o princípio da proporcionalidade.

$\mathrm{Na}$ verdade, o legislador reformador desperdiçou ótima oportunidade para resolver - ou ao menos amenizar - a questão problemática relativa à tipicidade do delito de estupro, já que esse nó górdio existia antes mesmo do advento da Lei de Reforma dos Crimes Sexuais em questão. Ou, ainda melhor (ou pior), persistia desde a entrada em vigor do próprio Código Penal de 1940.

Quando se voltam os olhos à Carta Magna e ao Estatuto Repressivo, deve-se verificar e sentir, particularmente in casu, a presença da segurança jurídica e da proporcionalidade. Aquela, teoricamente promovida pela tipicidade fechada; esta, percebida no quantum da pena privativa de liberdade presente no tipo penal, em seu preceito secundário, nos limites mínimo e máximo.

Inadmissível, portanto, a manutenção do tipo de estupro da forma como está construído, já que estão contidos na sua tipicidade elementos normativos imprecisos que o tornam aberto ${ }^{118}$ e postulam uma valoração singularmente especial por parte do magistrado ao analisar a situação em particular, afastando, destarte, toda e qualquer segurança jurídica.

Da mesma maneira, inaceitável a previsão abstrata da mesma pena privativa de liberdade para fatos diversos que podem surgir no caso concreto, os quais, a despeito de serem direcionados à mesma tipicidade formal, substancialmente, apresentam valoração jurídica e reprovação social diametralmente opostas, relegando, pois, a segundo plano, a proporcionalidade.

Tem-se, assim, que a (contínua) admissibilidade dessa espécie de crime sexual propicia julgamentos contraditórios e, em grande parte, injustos, ao conspurcar contra os princípios penais constitucionais ora referidos, perceptíveis há bastante tempo no Direito estrangeiro. ${ }^{119}$

118 A propósito, frisa Renato de Mello Jorge SILVEIRA: “A aceitação de certo grau de indeterminação no conteúdo do tipo pode até ser imprescindível em certos casos, mas nunca no sexual". In: Crimes sexuais: bases críticas para a reforma do direito penal sexual. São Paulo: Quartier Latin, 2008, p. 308 (grifou-se).

119 O Código Penal francês (Napoleônico) já previa, de forma autônoma, a existência do crime de "atentado violento ao pudor", distinto do "estupro", ocasião em que o mesmo se configurava desde os gestos "exercidos com violência contra uma pessoa com a intenção de ofender seu pudor", de maneira que "uma pluralidade de ofensas" podiam ser agrupadas nesse tipo penal. Já à época, notou-se o perigo: "os limites do atentado ao pudor não 
Tratando-se de Direito estrangeiro, seguindo trilha em sentido contrário à irracionalidade legislativa do direito penal brasileiro ora apontada, importa destacar a redação típica contida no Código Penal espanhol, que, também visando à tutela da liberdade sexual da pessoa nos artigos $178^{120}$ e $179^{121}$, delineia a incidência da lei penal sobre a conduta delitiva de forma a respeitar ambos os princípios (taxatividade e proporcionalidade), dicotomizando a tutela penal diante das divergentes faces da violência sexual, que, para o legislador brasileiro, apresentam-se unificadas.

Com efeito, observado o artigo 178 daquele codex, percebe-se que a tutela penal contida no mesmo reverbera junto à agressão sexual perpetrada mediante violência ou grave ameaça contra a liberdade sexual do indivíduo em seu sentido lato, culminando com a imposição de pena privativa de liberdade, variável de um a quatro anos. De outra banda, seu artigo 179 implica a tutela dirigida à agressão sexual (emprego de violência ou grave ameaça) consistente no acesso carnal por via vaginal, anal ou oral, ou na introdução de objetos ou membros corporais por uma das duas primeiras vias citadas, culminando este tipo penal com uma imposição de pena privativa de liberdade notoriamente mais severa, variando de seis a doze anos.

Dessa forma, desnecessário se faz que o exegeta depreenda grande esforço intelectual para verificar que, contrariamente à irracionalidade legislativa contida no artigo 213 do Código Penal brasileiro, o legislador espanhol - ressalte-se -, em verdadeiro respeito aos mencionados princípios da taxatividade e da proporcionalidade, ao prever a existência de uma gradação de pena entre as condutas que atingem a liberdade sexual do indivíduo em sentido lato e aquelas outras que atingem a sua liberdade sexual sob a forma de agressões objetivamente descritas na lei, focando, especialmente, aquelas denominadas, nesta oportunidade, de

começam aqui com os toques (...) mas criam-se palavras, diferenciam-se limiares, autorizando a transformar em crime aquilo que não o era, abrindo para um novo território de penalidade". VIGARELLO, Georges. História do estupro: violência sexual nos séculos XVI-XX. Rio de Janeiro: Jorge Zahar, 1998, p. 121-125.

120 "Art. 178. El que atentare contra la libertad sexual de otra persona, con violencia o intimidación, será castigado como responsable de agresión sexual con la pena de prisión de uno a cuatro años".

121 “Art. 179. Cuando la agresión sexual consista en acceso carnal por vía vaginal, anal o bucal, o introducción de miembros corporales u objetos por alguna de las dos primeras vías, el responsable será castigado como reo de violación con la pena de prisión de seis a 12 años". 
"condutas invasivas", proporcionou ares racionais às normas legais que têm por escopo reprimir os delitos contra a liberdade sexual naquele País, afastando-se sobremaneira da insegurança forjada pela expressão "outro ato libidinoso" que o legislador brasileiro insiste em manter como elemento do tipo, o qual conduz o intérprete à perigosa conclusão que aí estão contidos todos os atos de natureza sexual.

Infelizmente, a técnica legislativa adotada no Código Penal brasileiro para a construção do referido tipo penal, tal como já foi apontado, remete ao Judiciário o exercício de racionalidade relativo à definição daquilo que pode e deve ser entendido como "outro ato libidinoso".

Verificadas tais inconsistências legais em relação ao delito de estupro do artigo 213 do Código Penal, urge fazer uma análise jurídica voltada ao crime de estupro de vulnerável, previsto no artigo 217-A desse diploma repressivo, aqui denominado de "estupro na forma especial".

O tipo penal consistente no estupro de vulnerável identifica, na sua primeira parte, a mesma conduta prevista na forma básica do delito, ou seja, aquela em que o agente introduz seu pênis na vagina da mulher. No entanto, essa conjunção carnal pode ocorrer sem o consentimento da vítima $^{122}$ ou mesmo com a sua anuência, ciente o autor da sua idade (não maior de 14 anos). ${ }^{123}$

Na segunda parte da referida norma penal, tipifica-se a conduta de praticar com a vítima outro ato libidinoso. Igualmente, exige-se nesse caso que o sujeito ativo tenha conhecimento de que ela não apresenta, na data do fato, idade superior a 14 anos.

Duas questões importantes - e preocupantes - eclodem da interpretação técnico-jurídica do artigo 217-A, a saber: primeiro, se o elemento "outro ato libidinoso" engloba toda e qualquer prática de natureza sexual com o propósito de satisfação da libido do agente; segundo, se a idade da vítima deve ser analisada objetivamente, sem o questionamento

\footnotetext{
122 Não é demais registrar, que na hipótese em que vier a ocorrer o estupro de vulnerável com violência real ou grave ameaça, ainda que do ato resulte na vítima lesões corporais de natureza leve, a adequação típica será a mesma (artigo 217-A), devendo o meio executório servir, outrossim, para a dosimetria da pena a ser cominada ao agente, nos termos do artigo 59 do Código Penal, pois não há até o momento um tipo penal específico para essa situação fática.

123 Evidentemente, o estudo da vulnerabilidade nesta medida do trabalho não afasta a análise que se poderia realizar acerca da incidência do chamado "erro de tipo", relativamente à idade da vítima do delito.
} 
acerca das suas atitudes e dos seus conhecimentos de natureza sexual. Em outras palavras, qual o sentido que se deve atribuir à ideia de "vulnerabilidade", particularmente quanto à questão da idade da vítima.

Para se alcançar o significado de vulnerabilidade em relação à idade da vítima, pode-se afirmar, de maneira sumária, que tal compreende todas as pessoas vítimas do delito de estupro que não tenham mais de 14 anos, com supedâneo no disposto no artigo 217-A. Esta pode ser a melhor conclusão, mas existem outras disposições normativas fundamentadoras.

$\mathrm{Ou}$, ao contrário, o sentido de vulnerabilidade somente poderia vir com a constatação do caso concreto, reforçando-se assim a afirmação de Claus Roxin, para quem a capacidade de compreensão - para consentir - é matéria de fato, e, portanto, independe de limite de idade. ${ }^{124}$

Esses posicionamentos traduzem - e repetem -, na verdade, as discussões travadas pela doutrina e jurisprudência nacionais anteriormente à Lei $\mathrm{n}^{\mathrm{o}} 12.015 / 09$, com base nas ideias de que haveria presunção absoluta ou relativa de violência nos casos de vítimas com idade até 14 anos.

Nesse passo, tem-se, por exemplo, entendimentos recentes e que traduzem concepções e julgados anteriores à Lei $\mathrm{n}^{\circ}$ 12.015/09, com decisões no sentido de que a presunção de violência a que se referia o revogado artigo 224 do Código Penal no crime de estupro tem caráter relativo e, em certos casos, deve ser afastada, atentando-se para a realidade concreta dos fatos. ${ }^{125}$

Ora, decisum desse naipe proporciona a discussão acerca da tipicidade do fato descrito pelo novel artigo 217-A do Código Penal, com a redação que lhe foi dada pela Lei $n^{\circ} 12.015 / 09$, na medida em que surge um aparente conflito desse julgado com o texto legal em vigor.

Tal discussão pode ser levada a efeito, igualmente, a partir de uma recente decisão da $7^{\mathrm{a}}$ Câmara do Tribunal de Justiça do Rio Grande

124 ROXIN, Claus. Derecho penal, parte general, tomo I. $2^{\mathrm{a}}$ ed. Trad. Diego-Manuel Luzón Peña; Miguel Díaz y García Conlledo y Javier de Vicente Remesal. Madrid: Civitas, 1997, p. 538.

125 BRASIL. Tribunais Superiores. Superior Tribunal de Justiça (STJ). Disponível no site: $<$ http://www.stj.jus.br/portal_stj/publicacao/engine.wsp?tmp.area=398\&tmp.texto=10517 5>, p. 1. Acesso em 10/08/2015. No caso analisado pelo Superior Tribunal de Justiça, o réu era acusado de ter praticado estupro contra três menores, todas com 12 anos de idade, no entanto, o magistrado e o Tribunal de Justiça local o inocentaram, sob o argumento de que as meninas eram garotas de programa e "já se dedicavam à prática de atividades sexuais desde longa data" (id., ibid., p. 2). 
do Sul (TJRS), que absolveu um réu acusado de praticar estupro de vulnerável contra uma adolescente de doze anos de idade.

Segundo a argumentação desenvolvida no acórdão, relatado pela Desembargadora Naele Ochoa Piazzeta, confirmando a sentença que já absolvera o réu, a vulnerabilidade não deve ser entendida como um critério absoluto, mas precisa ser medida de acordo com as circunstâncias do caso concreto. Na hipótese em testilha, as informações consideradas pela relatora são no sentido de que aquele fato foi cometido sem violência e que havia plena concordância da suposta vítima, a qual se tratava, ademais, de pessoa já versada em contatos sexuais, a despeito da pouca idade. $^{126}$

Ocorre, porém, que melhor interpretação pode ser feita sobre a ideia de vulnerabilidade contida no artigo 217-A, tanto sob o prisma legal como, sobretudo, a partir da ótica das garantias constitucionais. E, com respeito ao primeiro, deve-se vislumbrar, primeiramente, a redação típica do citado dispositivo penal: punem-se as condutas de "ter" (conjunção carnal) ou "praticar" (ato libidinoso) com pessoa menor de 14 anos, diferentemente daquelas previstas no tipo fundamental do artigo 213, cuja subsunção se dá com o ato de "constranger" alguém (à prática de conjunção carnal ou outro ato libidinoso). Em virtude disso, correta a afirmativa de que "é praticamente impossível encontrar uma saída para afirmar que ter ou praticar são condutas que admitem alguma valoração da vontade do sujeito passivo quanto ao resultado da conduta". ${ }^{27}$

Em que pese essa avaliação, existem outras disposições normativas que podem legitimar a compreensão de que a prática da conjunção carnal ou outro ato libidinoso com pessoa não maior de 14 anos configura o citado tipo penal, entendendo-se, pois, a vítima como vulnerável.

A Constituição Federal de 1988 dispõe, no artigo 227, caput, que é dever da família, da sociedade e do Estado assegurar a toda criança e a todo adolescente direitos fundamentais, bem como estar todos obrigados a "colocá-los a salvo de toda forma de negligência, discriminação, exploração, violência, crueldade e opressão". E, no parágrafo $4^{\circ}$, acrescenta que: "A lei punirá severamente o abuso, a violência e a exploração sexual da criança e do adolescente".

${ }^{126}$ GENTIL, Plínio. Estupro de vulnerável consentido: uma absolvição polêmica. Disponível no site: <http://www.midia.apmp.com.br/arquivos/pdf/artigos/ 2012_estupro_vulneravel.pdf.>, p 1. Acesso em 10/08/2015.

127 Id., p. 2. 
Nesse sentido, inicialmente é possível afirmar que os fatos, penais ou não, que envolvam crianças e adolescentes exigem tratamento especial em função dessa garantia constitucional. Logo, as condutas praticadas em relação a eles, notadamente aquelas de conotação penal, ganham o contexto singular diante do qual surge a necessidade de se lhes conferir maior proteção jurídica.

Igualmente, o Estatuto da Criança e do Adolescente (Lei $\mathrm{n}^{\circ}$ 8.069/90) confere às pessoas em questão as mesmas garantias constitucionais (artigo $3^{\circ}$ ) e proteção integral $\left(\operatorname{artigo} 1^{\circ}\right.$ ). E, nos termos do artigo $2^{\circ}$, entende-se como criança o indivíduo cuja idade não ultrapassa os 12 anos, de modo que é considerado adolescente aquele com idade entre 12 anos completos e 18 incompletos.

Desta feita, pode-se concluir, conseguintemente, que "ter" conjunção carnal ou então "praticar" ato libidinoso com criança (menor de 12 anos) implica abuso sexual, tipificando-se o artigo 217-A, independentemente de seu eventual consentimento, o qual, se ocorreu, há que ser desconsiderado, na medida em que ela não apresenta capacidade de compreensão para tanto. ${ }^{128}$

Tratando-se de adolescente, muito embora ele possa ter discernimento no caso concreto, concernentemente à prática do ato sexual, diante de sua relativa capacidade de compreensão, ${ }^{129}$ à luz da garantia constitucional do artigo 227 da Carta Magna é absolutamente legal e legítimo que o legislador penal opte por indicar um limite mínimo de idade a partir do qual esse adolescente é capaz de entender e de querer, mesmo que tal limite seja distinto daquele especificado pela norma que define quem deve ser considerado criança ou adolescente.

Acrescente-se a isso que a Lei de Reforma dos Delitos Sexuais é posterior ao Estatuto da Criança e do Adolescente, de modo que, tratan-

\footnotetext{
${ }^{128}$ Segundo o Estatuto da Criança e do Adolescente, tratando-se de ato infracional, ou seja, a conduta descrita como crime ou contravenção penal, é preciso verificar a idade do adolescente à data do fato, de modo que as disposições da lei em questão somente são aplicáveis aos inimputáveis (menores de 18 anos), e as medidas sócioeducativas (que se referem às práticas infracionais), unicamente àqueles, e não às crianças, sujeitas apenas às medidas específicas de proteção (artigos 103-105). Logo, como as crianças não apresentam capacidade de entendimento e autodeterminação para a prática infracional, também lhes falta a capacidade de consentimento para o ato de natureza sexual.

${ }^{129}$ A afirmativa parte do mesmo raciocínio levado a efeito quando da análise do Estatuto da Criança e do Adolescente (Lei $n^{\circ}$ 8.069/90), nos exatos termos registrados na nota anterior.
} 
do-se de discernimento para a prática de ato de natureza sexual, inexiste capacidade de entendimento e autodeterminação relativamente à pessoa não maior de 14 anos, configurando-se abuso e, portanto, crime de estupro de vulnerável. ${ }^{130}$

Em função disso, deve-se refutar a tese de presunção relativa de violência fundamentada no fato de que o/a adolescente exercia anteriormente a prostituição como meio de vida, ou então de que houve consentimento da vítima (não maior de 14 anos). Argumentação nesse sentido não deve excluir a tipificação do delito, porque o bem juridicamente tutelado é a formação moral da criança ou do adolescente, visando a proteger a peculiar condição da pessoa em desenvolvimento. ${ }^{131}$

Por derradeiro, retorna à baila a seguinte questão: o elemento "outro ato libidinoso", ora contido no artigo 217-A, engloba toda e qualquer prática de natureza sexual com o propósito de satisfação da libido do agente?

Neste ponto, deve-se trabalhar com dois parâmetros, a saber: o respeito aos princípios da proporcionalidade e da taxatividade, e a observância do princípio da proteção integral à criança e ao adolescente, propugnados tanto pela Constituição Federal como pelo Estatuto da Criança e do Adolescente, tarefa essa, por sinal, muito delicada.

De toda sorte, a conciliação desses princípios viria com a tipificação das já denominadas "condutas invasivas" tidas com a pessoa não maior de 14 anos no delito de estupro de vulnerável, do artigo 217-A, afastando-se as possíveis ilações acerca de seu conhecimento, autodeterminação ou consentimento, relativos aos atos de natureza sexual.

${ }^{130}$ É de se notar, ainda, no tocante ao artigo 217-A, que o legislador penal não utilizou a expressão "criança", mas sim "menor de 14 anos", razão também pela qual há de ser afastada a relativização com fundamento no Estatuto da Criança e do Adolescente.

${ }^{131}$ Objetivando-se a tutela penal em questão, pode-se concluir que o tipo penal também visa a que as práticas sexuais com as pessoas não maiores de 14 anos sejam pura e simplesmente evitadas. Nesse sentido, o entendimento do Superior Tribunal de Justiça: "1. A violência presumida, prevista no art. 224, alínea a, do Código Penal, tem caráter absoluto, afigurando-se como instrumento legal de proteção à liberdade sexual do menor de 14 (catorze) anos, em razão de sua incapacidade volitiva. 2. O consentimento do menor de 14 (catorze) anos é irrelevante para a formação do tipo penal do estupro ou atentado violento ao pudor, pois a proibição legal é no sentido de coibir qualquer prática sexual com pessoa nessa faixa etária" (grifou-se). BRASIL. Tribunais Superiores. Superior Tribunal de Justiça (STJ). Disponível no site: <http://www.jusbrasil.com.br/jurisprudencia/2066952/embargos-de-divergencia-norecurso-especial-eresp-688211-sc-2007-0227141-6-stj>, p. 1. Acesso em 12/08/2015. 
Concomitantemente a tal raciocínio, a prática dos demais atos libidinosos levados a cabo com essa pessoa, também sem qualquer possibilidade de se invocar uma presunção relativa em face da sua conduta sexual, restaria afastada da subsunção típica ao artigo 217-A, pelo fato de o mesmo apresentar uma característica aberta, reveladora de imprecisão e insegurança jurídicas.

\section{$4 \quad$ O DELITO DE ESTUPRO NO NOVO CÓDIGO PENAL BRASILEIRO}

O Anteprojeto de Código Penal brasileiro - Projeto de Lei do Senado, no 236, de 2012 -, foi apresentado pela Comissão de Juristas ao Senador Pedro Taques em nove de julho desse ano, e ensejou, depois de submetido à revisão pela Comissão Temporária de Estudos da Reforma do Código Penal, presidida pelo mesmo parlamentar, um Projeto Substitutivo, que ainda tramita no Congresso Nacional. A proposta legislativa atual propõe a manutenção da tipificação do delito de estupro (seja comum ou especial - estupro de vulnerável) enquanto modalidade de crime contra a dignidade sexual, previsto agora no Título IV, Capítulos I e II, do novo diploma repressivo.

À primeira vista, parece que o legislador se convenceu da necessidade de reformular as condutas típicas relativas ao delito de estupro, resgatando, para isso, a aplicação dos princípios da taxatividade e proporcionalidade, observações que o autor fizera anteriormente, quando o Projeto 236 ainda não havia sido apresentado, em artigo jurídico publicado em revista especializada. ${ }^{132}$

$\mathrm{Na}$ esteira dos tipos penais contra a liberdade sexual previstos no Código Penal do Reino de Espanha, trazidos à baila em determinada medida deste trabalho, o "constrangimento", que é levado a efeito medi-

\footnotetext{
132 Trata-se do artigo jurídico do autor, intitulado: "O delito de estupro após o advento da Lei $n^{\circ} 12.015 / 09$ - questões controvertidas em face das garantias constitucionais", cujo trabalho foi apresentado durante o X Simpósio Nacional de Direito Constitucional, realizado pela ABDConst - Academia Brasileira de Direito Constitucional, em Curitiba/PR, durante os dias 24, 25 e 26 de maio de 2012 e publicado nos Anais do Simpósio. O artigo em questão foi premiado pela Academia como o melhor artigo científico do grupo de trabalho "Garantias constitucionais e Direito e Processo Penal: novas abordagens dos dilemas sociais". Disponível em: <www.abdconst.com.br/anais2.php>.
} 
ante violência ou grave ameaça, próprio desse tipo de crime, no Projeto 236 é previsto como ação nuclear de tipos fundamentais ou básicos para a prática de três diferentes condutas, as quais implicam a tipificação de três diferentes delitos, a saber:

Estupro - prática de ato vaginal, anal ou oral;

Manipulação e introdução sexual de objetos - introdução de objetos nas vias vaginal ou anal;

Molestamento sexual - prática de ato sexual diverso do estupro vaginal, anal e oral.

No caso das duas primeiras formas do delito contra a dignidade sexual, mantém-se as mesmas penas privativas de liberdade, ou seja, mínimo de seis e máximo de dez anos. Já para a terceira modalidade, a reprovação penal surge mais branda, com previsão de pena privativa de liberdade mínima de dois anos e máxima de seis anos. tipos penais.

Na sequência, pode-se verificar como se apresentam os citados

Estupro.

Art. 180. Constranger alguém, mediante violência ou grave ameaça, à prática de ato sexual vaginal, anal ou oral:

Pena - prisão, de seis a dez anos.

Parágrafo único. Se o agente pratica o crime mediante mais de uma das condutas descritas no caput, a pena será aumentada de um terço a dois terços, sem prejuízo da aplicação de outras causas de aumento previstas neste Título.

Manipulação e introdução sexual de objetos.

Art. 181. Constranger alguém, mediante violência ou grave ameaça, a suportar a introdução vaginal ou anal de objetos:

Pena: prisão, de seis a dez anos.

Molestamento sexual.

Ar. 182. Constranger alguém, mediante violência ou grave ameaça, ou se aproveitando de situação que dificulte a defesa da vítima, à prática de ato libidinoso diverso do estupro vaginal, anal e oral:

Pena - prisão, de dois a seis anos. 
Parágrafo único. Se o molestamento ocorrer sem violência ou grave ameaça, a pena será de um a dois anos. $^{133}$

Inicialmente, verifica-se que o novo legislador reformador, partindo de uma mesma ação nuclear ("constranger"), por meio de um mesmo meio executório ("violência ou grave ameaça") - e na hipótese do molestamento sexual, acrescentando "outro diverso" -, identifica as espécies de práticas sexuais realizadas com a vítima e confere graus diversos de reprovabilidade penal, de acordo com o caso específico. Interessante, neste momento, traçar um paralelo o com atual crime de estupro, em vigor com a redação conferida pela Lei $\S 1^{\circ}$..

No Capítulo anterior, restou demonstrado que ocorreu uma fusão dos antigos delitos de estupro e atentado violento ao pudor, culminando no crime de estupro, que, a partir do advento da referida lei, passou a tipificar, no único dispositivo legal (art. 213), práticas sexuais libidinosas as mais diversas, com menção específica, tão somente, à conjunção carnal.

O Projeto 236 propõe a manutenção do delito de estupro, restringindo, entretanto, a este universo típico apenas os atos sexuais vaginais, anais ou orais, considerados pelo legislador como os mais graves atentados à dignidade sexual do ser humano. Com isso, afasta da subsunção a este tipo penal os atos sexuais mais brandos, menos reprováveis, mas que, por se tratarem igualmente de atos libidinosos, justificam a intervenção do direito penal, ainda que de maneira menos intensa em relação àqueles casos. Para tanto, tipificou o crime de molestamento sexual.

Percebe-se, ainda, que raciocinando em conformidade com o legislador espanhol no que diz respeito à gravidade das condutas, mas optando por separá-las, o Projeto 236 traz a lume um tipo específico para os casos em que o constrangimento à dignidade sexual é levado a efeito por meio de objetos, e não partes do corpo humano. ${ }^{134}$ É a manipulação e

\footnotetext{
133 BRASIL. Senado Federal. Anteprojeto do novo código penal brasileiro. Disponível no site: <www.conjur.com.br/dl/anteprojeto-codigo-penal.pdf>, p. 84 . Acesso em 28/08/2015.

134 Reitere-se que o Código Penal espanhol, ao tratar dessa matéria, tipificou em apenas um artigo ambas as condutas de agressão sexual cometida por meio de membros do corpo humano ou de objetos, impactando na pena máxima prevista para o delito quando comparado ao tipo penal dos arts. 180 e 181 do Projeto 236 (até 12 anos, contra os 10 anos do
} 
introdução sexual de objetos. Inobstante tenha sido esta a opção legislativa, mantêm-se os mesmos limites da pena de prisão (seis a dez anos), inclusive muito próximos daqueles previstos no Código Penal espanhol.

Com a adoção desses procedimentos, relativamente aos delitos contra a dignidade sexual ora em comento, o Projeto 236 agasalha de maneira satisfatória a aplicação dos princípios penais constitucionais da taxatividade e proporcionalidade na construção dos tipos penais fundamentais ou básicos de constrangimento à prática de atos sexuais. Isto porque o legislador procede à cisão das condutas possíveis nessa seara sexual e, em cada caso, preceitua a reprovação penal específica de maneira balanceada com a gravidade de cada tipo de injusto.

Por seu turno, atraem também a atenção a causa especial de aumento de pena e a forma privilegiada criadas, respectivamente, para o delito de estupro e o de molestamento sexual. Vale a pena tratar dessas questões nesta oportunidade, ainda que de maneira sucinta, haja vista que os consectários dessas alterações poderiam ser objeto de longa e mais aprofundada discussão penal.

Analisando-se os elementos constitutivos do delito de estupro, nos termos apresentados pelo Projeto 236, percebe-se a natureza alternativa das condutas, porque as ações nucleares nele inseridas estão separadas pela conjunção alternativa "ou". Logo, no conflito aparente de normas, aplicando-se o princípio da alternatividade, o agente, que no caso concreto, por exemplo, pratica dois atos sexuais - conjunção carnal e anal -, desde que no mesmo contexto fático, responde uma vez por esse crime, afastando-se, desta feita, a ocorrência do concurso de crimes.

Antes de prosseguir, urge realizar breve retrospecto relativamente ao delito de estupro, antes e após o advento da Lei $n^{\circ} 12.015 / 09$. Anteriormente à edição da referida lei, nas situações em que o agente praticasse conjunção carnal com a vítima, mas também, viesse a praticar outros atos libidinosos, a exemplo do sexo anal e oral, estava sujeito à responsabilização penal por dois crimes: estupro (art. 213) e atentado violento ao pudor (art. 214), em concurso de crimes.

Posteriormente, com o advento da referida lei, que revogou o delito de atentado violento ao pudor, percebeu-se que isso acarretou um

projeto brasileiro), conforme se constata na redação do art. 179: "Cuando la agresión sexual consista en acceso carnal por vía vaginal, anal o bucal, o introducción de miembros corporales u objetos por alguna de las dos primeras vías, el responsable será castigado como reo de violación con la pena de prisión de seis a 12 años". 
benefício ao agente, que naquela mesma situação, a partir de então, responderia por crime único de estupro, já que os comportamentos mencionados (conjunção carnal + sexo anal e oral) foram previstos na mesma figura típica, cuja infração penal passou a ser entendida como um crime de ação múltipla ou de conteúdo variado, aplicando-se somente a pena abstratamente cominada ao art. 213 (tipo penal misto alternativo), uma única vez, afastando-se, dessa forma, o concurso de crimes.

Entretanto, surgiram entendimentos contrários a essa interpretação, provavelmente com o propósito, entre outras razões, de se evitar situações injustas sob o ponto de vista da sociedade em relação aos delitos dessa natureza, defendendo o reconhecimento do art. 213 como sendo um tipo misto cumulativo, e, desta feita, possibilitando o concurso de crimes no caso de o agente ter conjunção carnal com a vítima e também praticar outro ato libidinoso, ${ }^{135}$ e até mesmo a criação de um tipo penal híbrido, tendo como solução o crime único ou o concurso de crimes, a depender da sucessividade/simultaneidade ou não dos atos sexuais praticados no referido contexto fático. ${ }^{136}$

Voltando ao Projeto 236, muito provavelmente em virtude da interpretação doutrinária e jurisprudencial majoritárias que tem prevalecido sobre o assunto, vale dizer, de que o princípio da alternatividade deve ser mesmo aplicado nesses casos, o legislador inova ao prever a incidência de uma causa especial de aumento de pena na hipótese de o agente praticar o delito de estupro mediante mais de um ato sexual, e isso sem prejuízo da aplicação de outras majorantes previstas no Título IV (Crimes contra a Dignidade Sexual).

Desta feita, apresenta-se um caminho intermediário de reprovação penal no caso em que o agente cometa mais de um ato sexual violento contra a vítima, equidistante das hipóteses de ocorrência de crime único de estupro (enquanto tipo penal misto alternativo) e do concurso de crimes (enquanto tipo penal misto cumulativo ou tipo penal híbrido).

Define-se, assim, o estupro como um delito de ação múltipla ou de conteúdo variado, no qual tem aplicação o princípio da alternatividade,

\footnotetext{
135 AMYS NETO, Abrão. Estupro, estupro de vulnerável e ação penal. Disponível no site: <www.jus.com.br/artigos/13404/estupro-estupro-de-vulneravel-e-acao-penal>, p. 2. Acesso em 30/08/2015.

136 GRECO FILHO, Vicente. Uma interpretação de duvidosa dignidade (sobre a nova lei dos crimes contra a dignidade sexual). Disponível no site: <http://jus2 .uol.com.br/doutrina/texto.asp?id=13530>, p. 4 . Acesso em 30/08/2015.
} 
mas permitindo uma resposta penal mais grave quando o agente, no caso concreto, pratica mais de uma ação nuclear prevista no tipo, mantendo-se a natureza jurídica do mesmo (evitando-se a utilização do subterfúgio do concurso de crimes).

Quanto ao delito de molestamento sexual, contido no art. 182 do Projeto 236, confirma-se a preocupação do legislador com os princípios da proporcionalidade e da taxatividade (ainda que, neste caso, mediante uma leitura conjunta deste dispositivo legal com os dois anteriores), na medida em que se desvinculam dos crimes mais graves (arts. 180 e 181), em definitivo, os demais atos sexuais considerados menos reprováveis em comparação à cópula vagínica, ao sexo anal e ao sexo oral, bem como à introdução de objetos naquelas duas primeiras vias. Prevalece, finalmente, a racionalidade legislativa no processo de criação de normas penais incriminadoras envolvendo atos sexuais violentos, atentatórias à dignidade sexual da pessoa humana.

E em relação à forma privilegiada do delito de molestamento sexual pode-se indagar se tal tipificação atende adequadamente aos anseios do princípio da proporcionalidade ou não, pois é perfeitamente possível a invocação do princípio da ultima ratio do direito penal, tornando, com isso, a conduta prevista no parágrafo único do art. 182 do Projeto 236 um indiferente penal.

Ocorre que, no caso em comento, o legislador define limites mínimo e máximo de pena bem abaixo daqueles que são previstos para a conduta básica ou fundamental desenhada no caput do referido art. 182. A hipótese a que se refere o parágrafo único desse dispositivo legal é aquela em que o molestamento é praticado sem violência ou grave ameaça à vítima, haja vista que se trata, neste caso, de pessoa adulta e capaz. Logo, poder-se-ia entender que a conduta - que é de mero aborrecimento ou incômodo - não reflete suficiente importância social, merecimento de proteção penal e necessidade de intervenção desse ramo do direito. Tratase de algo parecido com os tipos contravencionais de importunação ofensiva ao pudor e de perturbação da tranquilidade. ${ }^{137}$

Nesse diapasão, urge apontar que o parágrafo único do art. 182 do Projeto 236 não deve subsistir, pois a conduta descrita nesse tipo penal

\footnotetext{
137 Dec.-lei no 3.688/42 - Lei das Contravenções Penais. "Art. 61. Importunar alguém, em lugar público ou acessível ao público, de modo ofensivo ao pudor. Pena: multa". "Art. 65. Molestar alguém ou perturbar-lhe a tranquilidade, por acinte ou por motivo reprovável. Pena: prisão simples, de 15 (quinze) dias a 2 (dois) meses, ou multa”.
} 
é dotada de características contravencionais. E, partindo-se da ideia de que as contravenções penais detalham condutas de baixa ou baixíssima gravidade, em respeito ao princípio da intervenção mínima do direito penal, propugna-se a sua retirada imediata do ordenamento jurídicopenal, cuja tutela deve ser reservada a outros ramos do direito. Aliás, esta foi a recente, inovadora e avançada opção do legislador penal espanhol, cuja reforma do atual código penal entrou em vigor no País recentemente, em $1^{\circ}$ de julho de 2015 . $^{138}$

Feitos os comentários sobre os delitos sexuais violentos propostos para o novo código penal (estupro, manipulação e introdução sexual de objetos e molestamento sexual), também é preciso apresentar breves considerações sobre os crimes contra a dignidade sexual de vulneráveis, restritas, todavia, às condutas do delito de estupro depois da Lei $\mathrm{n}^{\circ}$ 12.015/09. Eis aqui os crimes:

Estupro de vulnerável - ato de manter relação sexual vaginal, anal ou oral;

Manipulação ou introdução sexual de objetos em vulnerável realizar manipulação vaginal ou anal ou introduzir objetos em pessoa;

Molestamento sexual de vulnerável - constranger para praticar ato libidinoso diverso do estupro vaginal, anal ou oral.

Em todas as situações mencionadas, a vítima é pessoa menor de 13 anos de idade, a qual passa a ser considerada vulnerável no contexto dos crimes contra a dignidade sexual. Esses tipos penais estão descritos no Projeto 236 da forma que segue.

Estupro de vulnerável.

Art. 186. Manter relação sexual vaginal, anal ou oral com pessoa que tenha até doze anos:

Pena - prisão, de oito a doze anos.

$\S 1^{\circ}$. Incide nas mesmas penas quem pratica a conduta abusando de pessoa portadora de enfermidade ou deficiência mental, ou de quem, por

\footnotetext{
138 PALOMINO MARTín, José Maria. Reformas del Código Penal. Disponível no site: <www.palominoyasociadosabogados.com/admin/modules/administracion/documentos/archivos/docs/8703a5_Reformas_del _Codigo_Penal_2015_Tablas_comparativas.pdf>,p. 3. Acesso em 01/09/2015.
} 
qualquer outra causa, não pode oferecer resistência ou não possui o necessário discernimento.

$\S 2^{\circ}$. A pena será aumentada de um sexto até a metade se resultar gravidez ou doença sexualmente transmissível.

$\S 3^{\circ}$. Se o agente pratica o crime mediante mais de uma das condutas descritas no caput, a pena será aumentada de um a dois terços, sem prejuízo da aplicação de outras causas de aumento previstas neste Título.

Manipulação ou introdução de objetos em vulnerável.

Art. 187. Realizar manipulação vaginal ou anal ou introduzir objetos em pessoa que tenha até doze anos:

Penal: prisão, de oito a doze anos.

Molestamento sexual de vulnerável.

Ar. 188. Constranger alguém que tenha até doze anos à prática de ato libidinoso diverso do estupro vaginal, anal e oral:

Pena - prisão, de quatro a oito anos.

Parágrafo único. Incide nas mesmas penas quem pratica a conduta abusando de pessoa portadora de enfermidade ou deficiência mental, ou de que, por qualquer outra causa, não pode oferecer resistência ou não possui o necessário discernimento. ${ }^{139}$

Primeiramente, vale notar que o legislador do Projeto 236 opta pela redução da idade da pessoa considerada vulnerável, em comparação à reforma dos crimes contra a dignidade sexual realizada pela Lei $n^{\circ}$ 12.015/09, cujo art. 217-A a identifica como alguém com menos de 14 anos. Embora pareça razoável a redução da idade do vulnerável - pessoa com menos de 13 anos -, não foi utilizada a melhor e mais sensata técnica jurídica. Ao contrário, a redação tem um significado ambíguo: a referência "até doze anos" não afasta, por si só, as frações de ano (meses e dias) que se seguem aos doze anos completos. Logo, quem tem doze anos, alguns meses e dias, na verdade não tem nem mais nem menos de "até

\footnotetext{
${ }^{139}$ BRASIL. Senado Federal. Anteprojeto do novo código penal brasileiro. Disponível no site: <www.conjur.com.br/dl/anteprojeto-codigo-penal.pdf>, p. 85-86. Acesso em 02/09/2015.
} 
doze anos", haja vista que o vocábulo "até" estabelece um limite de ano, mas não de meses e dias. Portanto, a razão está com Paulo Queiroz, ao afirmar que alguém "só perde a condição de 'até doze anos' quando completa treze anos". ${ }^{140}$

Deveria então o legislador acompanhar a tradição brasileira nessa matéria, cujo Estatuto da Criança e do Adolescente se refere à pessoa "menor de 12 anos", ou, ainda, "pessoa de até 12 anos incompletos", ao invés de, simplesmente, "pessoa que tenha até doze anos".

Tal como faz para o delito de estupro, o legislador restringe o significado da redação do estupro de vulnerável, permitindo-lhe que alcance apenas os atos sexuais vaginais, anais e orais. Agindo desta maneira, atende-se ao princípio da taxatividade, já que o art. 186, em seu caput, apresenta redação mais precisa e fechada sob o ponto de vista da interpretação jurídico-penal.

Por sua vez, o $\S 1^{\circ}$ traz um tipo penal equiparado, cujos elementos recriam o dispositivo legal da presunção de violência que constava do antigo art. 224 do código penal, posteriormente revogado pela Lei $\mathrm{n}^{\circ}$ 12.015/09. Com exceção da questão relativa à idade - que, já com a referida lei, passou a compor elemento específico do delito de estupro de vulnerável, embora limitando a idade da vítima nessa condição até 14 anos, e não até $12-$, o novel $\S 1^{\circ}$ compreende vulnerável a vítima que não pode oferecer resistência à conduta do agente, no caso concreto, ou the falta discernimento, em virtude de causa distinta da condição da idade e da enfermidade ou deficiência mental, inovando ao acrescentar, para esta última hipótese, a expressão "abusando de pessoa".

Tratando-se de vítima com enfermidade ou deficiência mental, para fins de compreensão da vulnerabilidade que permita a incidência do $\S 1^{\circ}$ do art. 186 do Projeto 236, observa Paulo Queiroz, acertadamente, que "não basta a simples condição de portador de transtorno mental, devendo tratar-se de inimputável em razão dessa particular condição". ${ }^{141}$

O legislador também prevê causas especiais de aumento de pena aplicáveis ao delito de estupro de vulnerável, sendo uma das mesmas ( $§$

\footnotetext{
${ }^{140}$ QUEIROZ, Paulo. Projeto de reforma do código penal: crimes contra a dignidade sexual. Revista da EMERJ, Rio de Janeiro, v. 15, n. 60, out./ dez. 2012, p. 219.

141 QUEIROZ, Paulo. Projeto de reforma do código penal: crimes contra a dignidade sexual. Revista da EMERJ, Rio de Janeiro, v. 15, n. 60, out./dez. 2012. p. 225.
} 
$3^{\circ}$ do art. 186) idêntica ao estupro comum, ${ }^{142}$ ou seja, inobstante concebido como um delito de ação múltipla ou de conteúdo variado, permitindose assim a aplicação do princípio da alternatividade, a reprovação penal será mais grave quando o agente cometer mais de uma ação nuclear prevista nesse tipo. Trata-se, como já foi mencionado neste trabalho, de opção equidistante das hipóteses de ocorrência de crime único de estupro (tipo penal misto alternativo) e concurso de crimes (tipo penal misto cumulativo ou tipo penal híbrido).

Contudo, o legislador cria outra espécie de majorante, fazendo com que o direito penal recaia sobre o agente se em decorrência da sua conduta. De acordo com o $\S 2^{\circ}$ do art. 186, se da relação sexual mantida com pessoa de até 12 anos ou, se por meio dela, houver abuso de quem é portador de enfermidade ou deficiência mental, ou ainda, de alguém que não tem como oferecer resistência ou não apresenta o necessário discernimento em relação ao fato concreto, a vítima engravidar ou ser cometida de alguma doença sexualmente transmissível, o agente responderá pelo delito de estupro de vulnerável com incidência de outra causa especial de aumento de pena, sem prejuízo de outras que também possam recair sobre ele.

De outra banda, no que diz respeito ao delito de manipulação ou introdução de objetos em vulnerável, escapa à compreensão do jurista, ao voltar sua atenção à racionalidade legislativa, por qual ou quais razões o legislador do Projeto 236 não adota a mesma lógica para a composição dos elementos típicos do art. 187, tal como ocorre com o art. 181, pois tratam da mesma situação. É que, a despeito de tais dispositivos legais terem praticamente o mesmo nomen iuris, a redação dos mesmos apresenta muita disparidade, de modo que praticamente nada têm em comum.

Explica-se. O delito de manipulação ou introdução de objetos em vulnerável é praticado por meio da ação nuclear "realizar" (verbo não recomendável para definição de crime, devido ao seu caráter neutro), e não "constranger". A realização de manipulação vaginal ou anal, ou mesmo a introdução de objetos em pessoa de até 12 anos, pode configurar conduta atípica, pois não está previsto, entre os elementos típicos do art. 187, o elemento interno - entendido como essencial - "para fins libidinosos". Desta feita, exemplificativamente, ações de pais, médicos e outros profissionais da área da saúde podem ser consideradas indiferentes pe-

\footnotetext{
142 Quando da apresentação das novas formas do delito de estupro, o autor as classificou em duas espécies: comum (estupro) e especial (estupro de vulnerável). Cf. p. 18.
} 
nais. Quiçá seja por esses motivos que Paulo Queiroz aduz a manifesta inconstitucionalidade desse tipo penal. ${ }^{143}$

Adiante, o delito de molestamento sexual de vulnerável, que encontra tipificação no art. 188 do Projeto 236, pretende reprovar a prática de atos libidinosos praticados contra pessoas que tenham até 12 anos de idade, cujas condutas apresentam gravidade substancialmente menor se comparadas à conjunção carnal, ao sexo anal e ao sexo oral (art. 186), bem como em relação ao delito de manipulação ou introdução de objetos em vulnerável (art. 187).

Refletindo sobre o processo de legiferação desse novo tipo penal, vislumbra-se que o legislador observa o princípio da proporcionalidade ao criar abstratamente os limites mínimo e máximo da respectiva pena privativa de liberdade, a partir da análise do delito em comento com os crimes previstos nos dois artigos antecedentes, que também envolvem uma vítima vulnerável. No entanto, o resultado não é o mesmo quando se analisa a taxatividade do art. 188 .

Isto porque a presença da ação nuclear "constranger" - que no mencionado dispositivo de lei nada dispõe sobre qual é o meio executório para tanto - permite uma interpretação voltada à necessidade de dissentimento da vítima no caso concreto, de modo que, mesmo em se tratando de pessoa não maior de 12 anos, o consentimento na prática do ato libidinoso implica atipicidade da conduta, situação que evidentemente não pode ser aceita para fins de tutela penal sexual. ${ }^{144}$

Neste ponto, melhor seria que o legislador reformador mantivesse a ação nuclear "ter", já presente no atual delito de estupro de vulnerável (art. 217-A), cuja tipicidade se instalaria com a simples prática do ato libidinoso, afastando-se questionamentos sobre eventual constrangimento ou não da vítima, diante da própria situação fática de ser ela considerada uma pessoa vulnerável.

143 QUEIROZ, Paulo. Projeto de reforma do código penal: crimes contra a dignidade sexual. Revista da EMERJ, Rio de Janeiro, v. 15, n. 60, out./dez. 2012. p. 226.

${ }^{144}$ Inobstante a compreensão sobre a capacidade de entendimento e autodeterminação seja matéria de fato, como já foi registrado em alguma medida deste trabalho, citando-se Claus Roxin, na esteira da previsão estatutária contida na Lei n ${ }^{\circ}$ 8.069/90 (Estatuto da Criança e do Adolescente), presume-se a vulnerabilidade da vítima do delito sexual cuja idade não ultrapasse os 12 anos. Cf.: GRECO, Alessandra Orcesi Pedro; RASSI, João Daniel. Op. cit., p. 103. 
Vale ainda ressaltar a equiparação que o parágrafo único do art. 188 faz em relação ao tipo penal fundamental do delito de molestamento sexual de vulnerável, nos casos em que a vítima é pessoa portadora de enfermidade ou deficiência mental ou quem, por alguma outra causa, não pode oferecer resistência ou não possui o necessário discernimento em relação ao fato.

A situação em tela é idêntica àquela prevista no $\S 1^{\circ}$ do art. 186 (estupro de vulnerável), diferenciando-se, obviamente, quanto à ação nuclear e à pena privativa de liberdade cominada em abstrato. Trata-se da inclusão, no tipo do parágrafo único do art. 188, das antigas circunstâncias de presunção de violência que constavam da redação do art. 224 do Código Penal anteriormente à entrada em vigor da Lei no 12.015/09, com exceção daquela referente à idade da vítima.

\section{A IDADE DA VÍTIMA NOS CRIMES SEXUAIS CONTRA VULNERÁVEIS}

É imperioso discorrer, neste trabalho, um pouco mais sobre a questão da idade da vítima nos crimes sexuais envolvendo os chamados vulneráveis, com foco, portanto, no delito de estupro de vulnerável do atual art. 217-A e nos delitos dessa natureza, constantes dos arts. 186, 187 e 188 do Projeto 236 (novo código penal brasileiro): estupro de vulnerável, manipulação ou introdução de objetos em vulnerável e molestamento sexual de vulnerável.

Nos capítulos antecedentes, o autor chamou a atenção do leitor para as divergências que existem nos julgados do Superior Tribunal de Justiça em relação aos delitos sexuais, em especial no que se refere à idade da vítima para fins de tipificação do estupro de vulnerável, divergências essas que permeiam um sem número de julgados dos Tribunais dos Estados e do Distrito Federal.

Discutiu-se ainda e também com base nos entendimentos desencontrados da doutrina e da jurisprudência acerca da vexata quaestio natureza da presunção de violência (absoluta ou relativa) das pessoas menores de 14 anos, raciocinando em torno de seu suposto conhecimento e consciência em relação aos atos de natureza sexuais por elas ou com elas praticados. 
Defendeu-se, neste trabalho, a tese de que há uma garantia constitucional e legal visando à proteção integral de crianças e adolescentes, ou seja, respectivamente, das pessoas não maiores de 12 anos e daquelas a partir desta idade, porém menores de 18 anos. E ainda, que se tratando de adolescente, inobstante ele possa ter discernimento no caso concreto, concernentemente à prática do ato de natureza sexual, diante de sua relativa capacidade de compreensão, à luz da mencionada garantia constitucional (artigo 227 da Constituição Federal), é absolutamente legal e legítimo que o legislador infraconstitucional opte por indicar um limite mínimo de idade a partir do qual esse adolescente será considerado capaz de entender e de querer, particularmente, para fins penais dos delitos sexuais envolvendo essas pessoas, mesmo que tal limite seja distinto daquele especificado pela norma que define quem deve ser considerado criança ou adolescente.

Por derradeiro, apontou-se que, diante da prática sexual envolvendo pessoas não maiores de 14 anos, - nesse sentido, independentemente de se tratar do atual código penal ou cogitando-se da incidência do novo codex -, o fato de a criança ou adolescente até a referida idade possuir real compreensão do ato libidinoso, seja por conhecimentos obtidos em diversas fontes de informação ou então, devido a práticas anteriores e eventualmente reiteradas desses mesmos atos, nada disso é suficiente para afastar a tipificação daqueles delitos, pois eles são considerados vulneráveis.

Muito bem. Torna-se imperioso registrar, nesta ocasião, que as divergências existentes em torno da vítima considerada vulnerável, seja nos termos do atual art. 217-A, seja conforme preveem os arts. 186, $187 \mathrm{e}$ 188 do Projeto 236, estão fadadas ao desaparecimento, perecendo a tese de que, se a pessoa menor de 14 anos consente para a prática do ato libidinoso, demonstra possuir experiência sexual anterior ou até mesmo reste induvidosa a existência de relacionamento amoroso entre a vítima e o agente, estará afastada a tipificação do delito de estupro de vulnerável e, por consequência, da manipulação ou introdução de objetos em vulnerável e do molestamento sexual de vulnerável. Em outras palavras, o fato de a vítima do delito sexual contra vulnerável, portanto, pessoa menor de 14 anos, apresentar grau suficiente de discernimento sobre os assuntos da sexualidade, capacitada de entendimento e determinação, não afasta a ocorrência desse crime.

Esta conclusão pode ser extraída a partir de recente julgamento do Superior Tribunal de Justiça, em recurso especial repetitivo, represen- 
tativo da controvérsia relativa ao delito de estupro de vulnerável, originário em acórdão paradigmático prolatado pelo Tribunal de Justiça do Estado do Piauí, em cuja Corte Superior assentou-se a tese adiante transcrita, publicada em 10/09/2015.

Para a caracterização do crime de estupro de vulnerável, previsto no art. 217-A, caput, do Código Penal - e nos arts. 186, 187 e 188 do Projeto 236, na análise do autor -, basta que o agente tenha conjunção carnal ou pratique qualquer ato libidinoso com pessoa menor de 14 anos. O consentimento da vítima, sua eventual experiência sexual anterior ou a existência de relacionamento amoroso entre o agente e a vítima não afastam a ocorrência do crime. ${ }^{145}$

Nesse sentido, a egrégia Terceira Seção do Tribunal de Justiça, ao dar provimento, por unanimidade, ao recurso especial representativo da controvérsia e assentado a mencionada tese, a bem da verdade, retrata o pensamento, efetivamente enraizado na mente popular, em todos os níveis de instrução, que ninguém deve se envolver sexualmente com menores. Tal decisão impõe, sobretudo, um dever geral de abstenção ${ }^{146}$ da prática de atos sexuais com menores (neste caso, que não ultrapassam 14 anos) e reflete, indubitavelmente, o objetivo da lei penal em questão: proteger a dignidade sexual dessas pessoas, consideradas, em definitivo, vulneráveis sob o aspecto sexual.

No mais, resta apenas aguardar se o Projeto 236 (novo código penal brasileiro) será em definitivo aprovado da forma como se apresenta atualmente ou se ainda haverá alterações futuras.

\section{CONSIDERAÇÕES FINAIS}

\footnotetext{
${ }^{145}$ BRASIL. Tribunais Superiores. Superior Tribunal de Justiça (STJ). Disponível no site: <http://s.conjur.com.br/dl/stj-estupro-vulneravel-estupro-menor-14.pdf〉, p. 39. Acesso em 25/09/2015.

${ }^{146}$ Mastieri, João. Do delito de estupro. São Paulo. Revista dos Tribunais, 1982, p. 116.
} 
O delito de estupro, em ambas as modalidades, da forma como está tipificado no Código Penal, continuará sendo alvo de acirradas discussões e críticas pela doutrina e jurisprudência.

Urge, portanto, que o legislador promova nova alteração típica, respeitando os princípios da taxatividade e da proporcionalidade, em particular, para atender às garantias constitucionais e legais relativas à pessoa vulnerável nos delitos sexuais.

Há necessidade de que o legislador infraconstitucional construa os tipos penais de forma racional, a ponto de conferir segurança jurídica aos indivíduos da sociedade. Para tanto, deve se afastar da utilização da normativa aberta e graduar as espécies de ofensa à dignidade sexual da pessoa humana, buscando quantificar o mínimo e o máximo da pena privativa de liberdade a ser aplicada nesses casos, conforme o tipo de agressão e a qualidade da vítima.

Nesse sentido, o presente trabalho propõe determinadas alterações legislativas do crime de estupro, com suas respectivas justificativas, de maneira que se respeitem os citados princípios penais constitucionais e a partir da valoração concreta da ofensa realizada.

O elemento normativo que confere o colorido aberto ao delito de estupro, percebido na expressão "outro ato libidinoso", deve ser retirado do tipo penal, substituindo-o por determinados elementos que identifiquem uma violação à dignidade sexual da vítima equiparável à conjunção carnal, mas que não se confundam com a mesma, isto é, as chamadas "condutas invasivas", que podem ser verificadas no acesso vaginal, anal ou bucal, ou ainda, na introdução de membros corporais ou objetos por uma das duas primeiras vias (vaginal ou anal), com a presença sempre necessária na conduta do agente do fim libidinoso, ou seja, a finalidade de prazer sexual.

As demais práticas libidinosas distintas das retrocitadas (v.g.: carícias nas partes íntimas da pessoa; beijos lascivos; etc.), por sua vez, devem vir tipificadas como delito próprio no Código Penal e como exceções às condutas relacionadas no crime de estupro, de maneira a configurarem ofensas secundárias à dignidade sexual da pessoa humana. Desta feita, aqueles atos deixariam de configurar tão somente uma contravenção penal (importunação ofensiva ao pudor - artigo 61, ou perturbação da tranquilidade - artigo 65, ambos do Dec.-lei $n^{\circ} 3.688 / 41$ ) ou mesmo fato atípico e com reprimenda equidistante de ambas as tipificações (crime e contravenção). 
Tratando-se do delito de estupro na modalidade simples (artigo 213), devem permanecer como meios de execução a violência ou a grave ameaça para sua tipificação.

Já no que diz respeito ao delito de estupro na modalidade especial (artigo 217-A), - vale dizer, o estupro de vulnerável - , a manutenção da redação legal prevendo a subsunção da conduta do agente ao tipo em questão quando a vítima não é maior de 14 anos deve ser mantida, além do que a interpretação literal há de prevalecer, fazendo-se valer a vulnerabilidade da criança ou do adolescente nessa condição como forma de garantia da proteção integral, independentemente da existência de seu eventual consentimento, admitindo-se apenas o afastamento típico tão somente na hipótese de erro inevitável, compreendido este quando o agente é induzido a erro em relação à idade da vítima pelo fato de ela apresentar compleição física precocemente desenvolvida.

O novo dispositivo em questão tutela a proteção integral do ser humano ainda criança ou do adolescente não maior de 14 anos, cuja integridade sexual necessita ser penalmente garantida contra os atos libidinosos inerentes ao tipo fundamental - conjunção carnal e condutas invasivas, - não cabendo quaisquer discussões sobre a inocência desse indivíduo em assuntos sexuais.

Nesse ponto, duas observações são importantes: primeiro, práticas libidinosas distintas da conjunção carnal e das condutas invasivas devem ser tipificadas de maneira autônoma, porém com um acréscimo da reprimenda no próprio tipo devido à idade da vítima; segundo, violência ou grave ameaça, se empregadas contra a vítima nessas condições particulares, demandam aumento da pena privativa de liberdade ainda maior, diante do dissenso na prática do ato sexual.

Acredita-se que a ratio legis desse tipo penal foi a de tutelar integralmente a criança e o adolescente até 14 anos, os quais se acham em processo de formação, seja no plano biológico, moral ou psicológico, circunstâncias essas que configuram o caráter de vulnerabilidade a que tais indivíduos estão expostos, especialmente na seara sexual, fator que legitima o legislador penal a criminalizar com maior rigor o delito de estupro contra as pessoas com a referida idade.

Relativamente ao Projeto 236 (novo código penal brasileiro), este agasalha de maneira satisfatória a aplicação dos princípios penais constitucionais da taxatividade e proporcionalidade na construção dos tipos penais fundamentais ou básicos de constrangimento à prática de atos 
sexuais, pois o legislador realiza a cisão das condutas possíveis na seara sexual e, em cada caso, reprova de forma razoável as condutas típicas, considerando a gravidade de cada tipo de injusto.

Por fim, urge apontar para uma séria omissão no bojo da proposta: inexiste referência às formas qualificadas do delito de estupro na hipótese de superveniência de lesão grave ou morte à vítima da agressão sexual. Trata-se de um problema que deve ser superado antes de se concluir a aprovação do novo código penal brasileiro, evitando-se assim possível conflito de normas penais.

\section{REFERÊNCIAS BIBLIOGRÁFICAS}

ALVES, Eliete. Alcântara Machado: um perfil do intelectual e político paulista e o projeto do código criminal brasileiro (1937/42). Dissertação de Mestrado. São Paulo: Pontifícia Universidade Católica de São Paulo, 1989.

AMYS NETO, Abrão. Estupro, estupro de vulnerável e ação penal. Disponível no site: <www.jus.com.br/artigos/13404/estuproestupro-de-vulneravel-e-acao-penal>. Acesso em 30/08/2015.

BARROS, Sérgio Resende de. Noções sobre poder constituinte. Disponível no site: <http://www.srbarros.com.br/pt/nocoes-sobrepoder-constituinte.cont>. Acesso em 02/08/2015.

BITENCOURT, Cezar Roberto. Tratado de direito penal: parte especial, v. 4. $5^{\text {a }}$ ed. São Paulo: Saraiva, 2011.

BRASIL. Senado Federal. Anteprojeto do novo código penal brasileiro. Disponível no site: <www.conjur.com.br/dl/anteprojeto-codigo-penal.pdf>. Acesso em 28/08/2015.

BRASIL. Tribunais Superiores. Superior Tribunal de Justiça (STJ). Disponível no site: <http://www.jusbrasil.com.br/jurisprudencia/2066952/embargosde-divergencia-no-recurso-especial-eresp-688211-sc-20070227141-6-stj>. Acesso em 12/08/2015.

BRASIL. Tribunais Superiores. Superior Tribunal de Justiça (STJ). Disponível no site: <http://s.conjur.com.br/dl/stj-estuprovulneravel-estupro-menor-14.pdf $>$. Acesso em 30/09/2015. 
BRASIL. Tribunais Superiores. Superior Tribunal de Justiça (STJ). Disponível no site: <http://www.stj.jus.br/portal_stj/publicacao/engine.wsp?tmp.area= 398\&tmp.texto=105175>. Acesso em 10/08/2015.

BRUNO, Aníbal. Direito penal, parte geral - t. 1. $5^{\mathrm{a}}$ ed. Rio de Janeiro: Forense, 2005.

CAMARGO, Joaquim Augusto de. Direito penal brasileiro. $2^{\text {a }}$ ed. São Paulo: Revista dos Tribunais, 2005.

CINTRA, Antonio Carlos de Araújo; GRINOVER, Ada Pellegrini; DINAMARCO, Cândido Rangel. Teoria geral do processo. $27^{\mathrm{a}}$ ed. São Paulo: Malheiros, 2011.

CÓDIGOS ELECTRÓNICOS. Código penal y legislación complementaria. Madrid: Boletín Oficial del Estado, 2015. Disponível no site: <http://boe.es/legislacion/codigos/codigo.php?id=038_Codigo_Pen al_y_legislacion_complementaria\&modo=1>. Acesso em 09/08/2015.

DÍEZ RIPOLLÉS, José Luiz. La racionalidad de las leyes penales. Madrid: Trotta, 2003.

DOTTI, René Ariel. Curso de direito penal: parte geral. $3^{\mathrm{a}}$ ed. São Paulo: Revista dos Tribunais, 2011.

ESTEFAM, André. Crimes sexuais - Comentários à Lei $n^{\circ}$ 12.015, de 7 de agosto de 2009. São Paulo: Saraiva, 2009.

FRAGOSO, Heleno Cláudio. Lições de direito penal. $16^{\mathrm{a}}$ ed. Rio de Janeiro: Forense, 2003.

FRANCO, Alberto Silva et. al. Código penal e sua interpretação jurisprudencial, v. 1, t. 2. $6^{\text {a }}$ ed. São Paulo: Revista dos Tribunais, 1997.

FREITAS, Vladimir Passos de. No Brasil, a história do Direito ainda é pouco estudada. Disponível no site: http://www.conjur.com.br/2010-jun-28/segunda-leitura-brasilhistoria-direito-estudada. Acesso em 08/08/2015.

GARCIA, Basileu. Instituições de direito penal, v. 1, t. 1. $4^{\text {a }}$ ed. São Paulo: Max Limonad, 1973.

GENTIL, Plínio. Estupro de vulnerável consentido: uma absolvição polêmica. Disponível no site: <http://www.midia.apmp.com.br/arquivos/pdf/artigos/2012_estupr o_vulneravel.pdf. $>$. Acesso em 10/08/2015.

GOMES, Luiz Flávio; CUNHA, Rogério Sanches; MAZZUOLI, Valério de Oliveira. Comentários à reforma criminal de 2009 e à 
Convenção de Viena sobre o direito dos tratados. São Paulo: Revista dos Tribunais, 2009.

GRECO, Alessandra Orcesi Pedro; RASSI, João Daniel. Crimes contra a dignidade sexual. São Paulo: Atlas, 2010.

GRECO FILHO, Vicente. Uma interpretação de duvidosa dignidade (sobre a nova lei dos crimes contra a dignidade sexual). Disponível no site: <http://jus2.uol.com.br/doutrina/texto.asp?id=13530>. Acesso em 30/08/2015.

GRECO, Rogério. Curso de direito penal: parte especial, v. 3. $8^{\mathrm{a}}$ ed. Rio de Janeiro: Impetus, 2011.

GUSMÃO, Chrysolito de. Dos crimes sexuais. $6^{\mathrm{a}}$ ed. Rio de Janeiro: Freitas Bastos, 2001.

HOFFBAUER, Nélson Hungria. A autoria intelectual do Código Penal de 1940. In: Conferência pronunciada na Faculdade Livre de Direito do Rio de Janeiro, 1954.

HOFFBAUER, Nélson Hungria; LACERDA, Romão Côrtes de. Comentários ao código penal, v. VIII. $4^{\text {a }}$ ed. Rio de Janeiro: Forense, 1959.

MARCÃO, Renato; GENTIL, Plínio. Crimes contra a dignidade sexual: comentários ao Título VI do Código Penal. São Paulo: Saraiva, 2011.

MARTINS, José Renato. O delito de estupro após o advento da Lei $n^{\circ}$ 12.015/09: questões controvertidas em face das garantias constitucionais. Anais do X Simpósio de Direito Constitucional da ABDConst. Curitiba: ABDConst, 2013.

MARTINS, José Salgado. Sistema de direito penal brasileiro. Rio de Janeiro: José Konfino, 1967.

Mastieri, João. Do delito de estupro. São Paulo. Revista dos Tribunais, 1982.

MIRABETE, Julio Fabbrini. Manual de direito penal: parte especial, v. 2. $28^{\mathrm{a}}$ ed. São Paulo: Atlas, 2011.

NADER, Paulo. Introdução ao estudo do Direito. $33^{\mathrm{a}}$ ed. Rio de Janeiro: Forense, 2011.

NUCCI, Guilherme de Souza. Crimes contra a dignidade sexual: comentários à Lei 12.015, de 7 de agosto de 2009. São Paulo: Revista dos Tribunais, 2009.

PALOMINO MARTÍN, José Maria. Reformas del Código Penal. Disponível no site: <www.palominoyasociadosabogados.com/admin/modules/administracion/documentos/archivo 
s/docs/8703a5_Reformas_del_Codigo_Penal_2015_Tablas_compa rativas.pdf $>$. Acesso em 01/09/2015.

PÉREZ LUÑ̃, Antonio Enrique. Derechos humanos, estado de derecho y constitución. 9a ed. Madrid: Tecnos, 2005.

PIERANGELLI, José Henrique. Códigos penais do Brasil. Evolução histórica. Bauru/SP: Javoli, 1980.

PRADO, Luiz Regis. Curso de direito penal brasileiro, v. 2. $7^{\text {a }}$ ed. São Paulo: Revista dos Tribunais, 2008.

QUEIROZ, Paulo. Projeto de reforma do código penal: crimes contra a dignidade sexual. Revista da EMERJ, Rio de Janeiro, v. 15, n. 60, out.-dez. 2012.

RAMOS JUNIOR, Antonio de Paula. Commentario ao código criminal brasileiro. Rio de Janeiro: Carioca, 1875.

REALE, Miguel. Lições preliminares de Direito. $27^{\mathrm{a}}$ ed. São Paulo: Saraiva, 2009.

ROLIM, Luiz Antonio. Instituições de direito romano. $4^{\mathrm{a}}$ ed. São Paulo: Revista dos Tribunais, 2010.

ROXIN, Claus. Derecho penal, parte general, tomo I. $2^{\mathrm{a}}$ ed. Trad. DiegoManuel Luzón Peña; Miguel Díaz y García Conlledo y Javier de Vicente Remesal. Madrid: Civitas, 1997.

SIDOU, J. M. Othon. Do conceito de stuprum entre os delitos sexuais no direito romano. In: Revista da Faculdade de Direito de Caruaru/Asces, v. 1, no 1, 1960.

SILVEIRA, Renato de Mello Jorge. Crimes sexuais: bases críticas para a reforma do direito penal sexual. São Paulo: Quartier Latin, 2008.

SIQUEIRA, Galdino. Tratado de direito penal: parte geral, t. 1. São Paulo: José Konfino, 1947.

VIGARELlO, Georges. História do estupro: violência sexual nos séculos XVI-XX. Rio de Janeiro: Jorge Zahar, 1998. 
